\title{
Primary Cilia and Mammalian Hedgehog Signaling
}

\author{
Fiona Bangs and Kathryn V. Anderson \\ Developmental Biology Program, Sloan Kettering Institute, Memorial Sloan Kettering Cancer Center, \\ New York, New York 10065 \\ Correspondence: k-anderson@ski.mskcc.org
}

It has been a decade since it was discovered that primary cilia have an essential role in Hedgehog $(\mathrm{Hh})$ signaling in mammals. This discovery came from screens in the mouse that identified a set of genes that are required for both normal Hh signaling and for the formation of primary cilia. Since then, dozens of mouse mutations have been identified that disrupt cilia in a variety of ways and have complex effects on Hedgehog signaling. Here, we summarize the genetic and developmental studies used to deduce how Hedgehog signal transduction is linked to cilia and the complex effects that perturbation of cilia structure can have on Hh signaling. We conclude by describing the current status of our understanding of the cell-type-specific regulation of ciliogenesis and how that determines the ability of cells to respond to Hedgehog ligands.

$\mathrm{H}_{\mathrm{i}}^{\mathrm{c}}$ edgehog $(\mathrm{Hh})$ is one of a handful of signaling pathways that is used repeatedly for intercellular communication in development. $\mathrm{Hh}$ is critical for the development of nearly every organ in mammals, as well as in homeostasis and regeneration, and Hh signaling is disrupted in several types of cancer. Unlike other core developmental signaling pathways, vertebrate $\mathrm{Hh}$ signaling is completely dependent on a highly specialized organelle, the primary cilium.

The $H h$ gene was discovered in Drosophila based on the striking phenotype of fly larvae that lack Hh-the mutants do not develop the segmented anterior-to-posterior body plan and have ectopic denticles resembling a Hedgehog (Nüsslein-Volhard and Wieschaus 1980). Mutations in other genes with related phenotypes defined a signaling pathway in which $\mathrm{Hh}$ is the ligand that acts through the membrane receptor Patched (PTCH1) and the seven transmembrane spanning protein Smoothened (SMO) to control the activity of a transcription factor Cubitus interruptus (Ci) (Forbes et al. 1993; Ingham 1998). In the mid-1990s, embryological experiments in chicks and targeted mutations in the mouse homologs of the Drosophila $\mathrm{Hh}$ pathway genes showed that the Hh signaling pathway is also critical for the development of many tissues and organs in vertebrates. Both the core players and their pathway relationships are conserved (Fig. 1) (Ingham and McMahon 2001). Because of this evolutionary conservation, it was completely unexpected when phenotype-based genetic screens in the mouse identified a set of proteins required for the formation of primary cilia that were also required

Editors: Wallace Marshall and Renata Basto

Additional Perspectives on Cilia available at www.cshperspectives.org

Copyright (C) 2017 Cold Spring Harbor Laboratory Press; all rights reserved; doi: 10.1101/cshperspect.a028175 Cite this article as Cold Spring Harb Perspect Biol 2017;9:a028175 
F. Bangs and K.V. Anderson

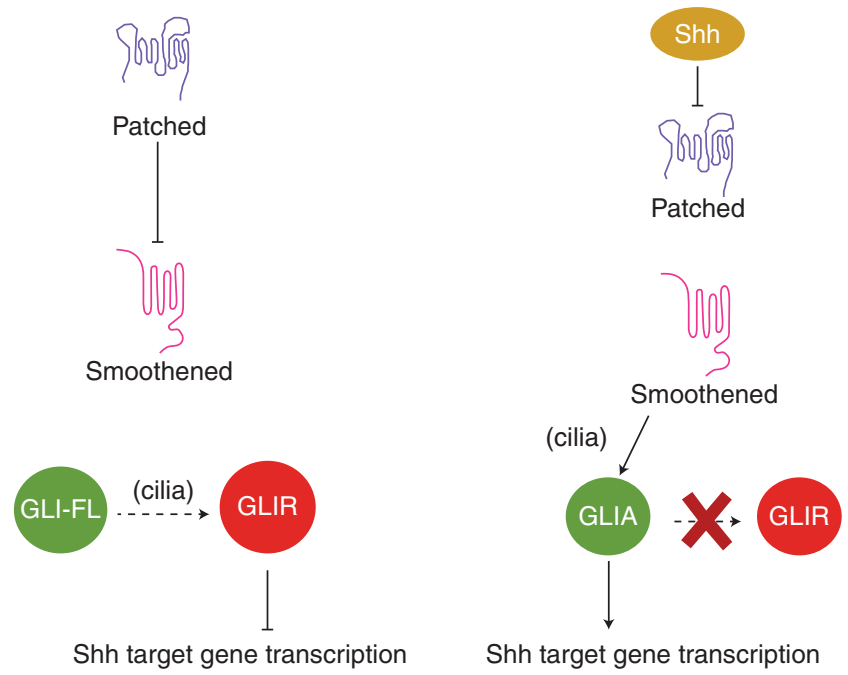

Figure 1. The backbone of the Hedgehog $(\mathrm{Hh})$ signal transduction pathway. The core of the Hh signaling pathway is conserved between Drosophila and vertebrates. In the absence of ligand, the Hh receptor Patched (PTCH1) keeps the pathway off by inhibiting the activity of the seven transmembrane-domain protein Smoothened (SMO). When SMO is inactive, the GLI/Ci (glioblastoma/Cubitus interruptus) transcription factors are proteolytically processed to make a transcriptional repressor that binds to Hh target genes and blocks their transcription. Binding of $\mathrm{Hh}$ to PTCH1 inhibits its activity, relieving the repression of SMO, which promotes conversion of full-length GLI/Ci into a transcriptional activator. In vertebrates, cilia are required for the production of both GLI-repressor and GLI-activator.

for mammalian (but not Drosophila) Hh signaling. The relationship between primary cilia and mammalian Hh signaling has turned out to be fascinating, complex, and directly relevant for specific human diseases, the ciliopathies.

Here, we describe the nature of primary cilia Hh-dependent patterning during mammalian development, with a primary focus on proteins that have been shown to affect Hh signaling in vivo in genetic studies. The combination of genetics, developmental biology, and cell biology has provided overwhelming evidence that mammalian Hh signal transduction absolutely depends on the primary cilium, defined the features of the cilium that are important for signaling, and characterized how different changes in cilia structure have distinct effects on $\mathrm{Hh}$ signaling. From these studies, the view emerges that $\mathrm{Hh}$ signaling and the primary cilium have coevolved, concentrating critical signaling components in the very small volume at the tip of the cilium to allow efficient responses to low levels of ligand.

\section{HEDGEHOG SIGNALING IN MAMMALIAN DEVELOPMENT}

There are three mammalian Hh proteins, Sonic $(\mathrm{SHH})$, Indian (IHH), and Desert (DHH). SHH and IHH have important, and sometimes overlapping, functions in many tissues. $\mathrm{SHH}$ has particularly striking roles in specification of cell types in the nervous system and in patterning of the limbs, whereas IHH has critical roles in skeletal development. Many studies have connected both SHH and IHH signaling to the primary cilium (see below). DHH appears to be restricted to the gonads and may also depend on primary cilia for its activity (Nygaard et al. 2015).

Drosophila Hedgehog has important roles in the patterning of adult organs, such as the eye, wing, and leg (Burke and Basler 1997). In these contexts, Hh acts as a short-range inducer of cell fate, inducing target gene expression in a range of 2-3 cell diameters away from the source of the signal. Drosophila Hh can activate 
expression of secreted proteins, such as Dpp (Bmp4) that can move further in tissues; as a result, Drosophila $\mathrm{Hh}$ has a profound role in the patterning of entire organs.

In contrast to the short-range signaling of Drosophila, the vertebrate $\mathrm{Hh}$ proteins can act over a field of cells that are many cell diameters away from the source of the protein. In neural patterning, $\mathrm{SHH}$ is first expressed in the notochord, which lies below the neural tube, and acts directly on cells in the ventral half of the neural tube to specify neural progenitors (Fig. 2) (Briscoe and Ericson 2001), and it appears that cells at least 20 cell diameters away from the source respond to Shh. In the limb, Shh is expressed in a classical organizer, the zone of polarizing activity (ZPA), and influences the pattern across most of the developing limb, again at a distance from its source (Ahn and Joyner 2004; Harfe et al. 2004). Indian hedgehog also acts at a distance to control proliferation and differentiation of chondrocytes (Long et al. 2001; Mak et al. 2008). Thus, one significant difference between Hh signaling in vertebrates and Drosophila appears to be that Hh ligands act at greater distances from their source in vertebrates; we hypothesize that long-range signaling requires a sensitized signal transduction system dependent on the primary cilium.

\section{INTRAFLAGELLAR TRANSPORT IS REQUIRED FOR SHH SIGNAL TRANSDUCTION IN THE MOUSE EMBRYO}

In the developing mouse embryo, perhaps the best-studied function of Shh is to direct patterning of neural progenitors, in which molecular markers make it possible to distinguish six different cell types that are specified by different levels of Shh activity (Briscoe and Ericson 2001; Dessaud et al. 2008). SHH made by the notochord induces formation of the floor plate and then specifies five additional neural cell typesV3 interneuron progenitors are specified adjacent to the floor plate by prolonged high levels of Shh signaling; motor neurons are determined by lower levels of Shh activity; and more dorsal interneurons are specified by yet lower levels of Shh. The final activity of the pathway depends on both ligand concentration and duration of exposure to ligand, and final cell fate depends on a regulatory network set into motion by SHH (Dessaud et al. 2007; Balaskas et al. 2012). In the absence of $\mathrm{SHH}$ or its positive effector SMO, ventral neural cell types fail to be specified, whereas loss of the negative regulator PTCH1 leads to the formation of ventral cell types by all neural progenitors (Fig. 2).

The seminal discovery that linked the primary cilium to Hedgehog signaling in the mouse came from the characterization of chemically induced mutations, such as the wimple mutation that lacked Shh-dependent ventral neural cell types and affected genes that encoded intraflagellar transport (IFT) proteins (Huangfu et al. 2003). IFT is the process by which the cilium is assembled and maintained. It is powered by two conserved, dedicated microtubule motors - anterograde transport from the base to the tip depends on a plus-end-directed heterotrimeric kinesin-2 complex, KIF3a, KIF3b, and KIF associated protein 3 (KAP3) (Cole 1999) and retrograde transport from the tip to the base requires the minus-end-directed cytoplasmic dynein 2 motor made up of a heavy chain, an intermediate chain, light intermediate chain, and several light chains (Hou and Witman 2015). These motors are coupled to the cargos by large electron-dense IFT trains, made up of two protein complexes, IFT-A and IFT-B (Pigino et al. 2009; Behal and Cole 2013).

Map-based cloning showed that the wimple mutation disrupted the gene encoding IFT172, an IFT-B complex protein, resulting in a complete lack of primary cilia. The same screen identified a partial loss-of-function allele of another IFTB complex protein, IFT88, which partially disrupted cilia assembly and showed a milder disruption of neural patterning. Targeted null alleles of Ift 88 and Kif $3 a$ also caused the complete absence of cilia accompanied by a loss of Shh-dependent ventral neural cell types. Although wimple mutant embryos lacked ventral neural cell types, the mutants still expressed $\mathrm{SHH}$, suggesting that without a cilium these mutants are unable to respond to Shh signaling (Huangfu et al. 2003). It was subsequently discovered that null mutations in other IFT-B 
F. Bangs and K.V. Anderson

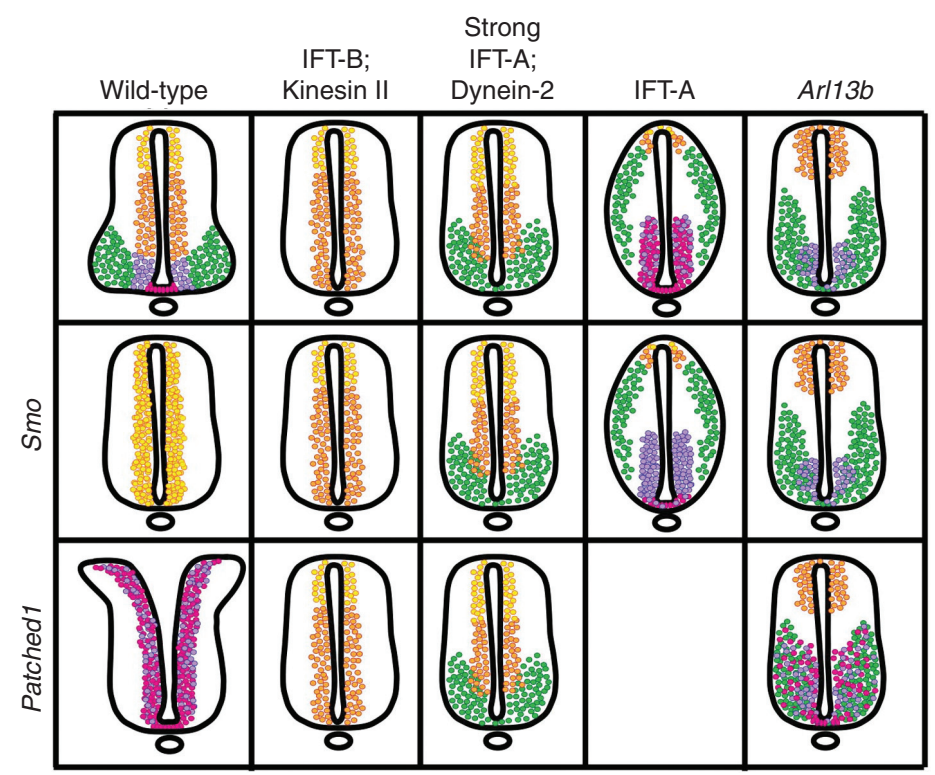

Figure 2. Mutations in cilia genes alter Hedgehog ( $\mathrm{Hh}$ )-dependent neural patterning. Schematics of the spatial distribution of neural cell types in the developing lumbar neural tube in mutants with abnormal cilia. Dorsal up, ventral down; the notochord is the small oval below the neural tube. SHH ligand released from the notochord and floorplate patterns the dorsoventral axis of the neural tube. The highest levels of Shh signaling specify floorplate cells ( pink). Dorsal to the floorplate are V3 neural progenitors, which also require high levels of Shh signaling (magenta). Motor neurons (green) require Shh but are specified at lower concentrations of ligand. V2, V1, and V0 interneurons (orange) require even lower levels of Shh activity. Dorsal progenitors (yellow) are specified by default, and high levels of Shh signaling inhibit the specification of dorsal progenitors. Smo mutant embryos fail to specify ventral neural subtypes and all neural progenitors follow a dorsal fate. In Patched 1 mutant embryos, all neural progenitors follow a ventral fate and express markers of the floorplate and V3 neural progenitors. Mouse embryos that lack a core intraflagellar transport (IFT-B) protein or kinesin-II lack primary cilia and therefore are unable to respond to Hh signaling; these mutants lack floorplate, V3 interneurons, and most motor neurons, V0-V2 interneurons and dorsal cell types extend ventrally, but V0-V2 interneurons are specified. Dync2h1 mutants, which lack the heavy chain of the dynein retrograde IFT motor and strong loss of IFT-A mutant embryos, have very short, bulged primary cilia and cannot transduce Hh signals efficiently; these mutants lack floor plate V3 interneurons and some motor neurons. In combination with Shh, Smo, or Patched1, double mutant embryos resemble single dynein or strong IFT-A mutants indicating that like IFT-B these components of the cilium assembly machinery are required downstream from SMO and PTCH1. Surprisingly, IFT-A mutant embryos that have a milder effect on cilia morphology (e.g., with cilia of near-normal length and bulged tips) have the opposite effect on neural patterning, with expanded ventral neural cell types. Cilia in Arl13b $b^{h n n / h n n}$ mutant embryos have structural defects in the microtubule axoneme, and the mutants fail to specify both the most ventral and most dorsal neural cell types. Double mutants that lack both a cilia component and Smo or Patched 1 have phenotypes similar to the cilia single mutants, indicating that the cilia machinery is required downstream from Ptch1 and Smo.

genes (IFT52, IFT54, and IFT57) also block cilia formation and Shh-dependent specification of ventral neural cell types (Table 1), providing strong evidence that the primary cilium is required for a cell to receive Shh signals.

Double-mutant analysis defined the step in the $\mathrm{Hh}$ signaling pathway that requires
IFT. PTCH1, the Hh receptor, is a negative regulator of $\mathrm{Hh}$ signaling. Ptch $1^{-/-}$mutant embryos die at E9.0 and express markers of ventral neural cell types (floor plate and V3 interneuron progenitors) throughout the neural plate, even far from the source of $\mathrm{SHH}$ (Fig. 2). In contrast, double mutants that 
Cilia and Hedgehog Signaling

Table 1. Subtle changes in cilia structure can decrease or increase Hh pathway activity, suggesting that the cilium provides more than just a permissive context for Hh signaling

\begin{tabular}{|c|c|c|c|}
\hline Mouse gene & Function in cilia & $\begin{array}{l}\text { Mouse embryo Hh pathway null phenotype } \\
\text { (neural and limb) }\end{array}$ & Human phenotype \\
\hline Kif $3 a$ & $\begin{array}{l}\text { Anterograde IFT } \\
\text { motor }\end{array}$ & $\begin{array}{l}\text { Loss of SHH-dependent ventral neural cell } \\
\text { types; polydactyly; midgestation } \\
\text { lethality (Huangfu et al. 2003) }\end{array}$ & \\
\hline Dync $2 h 1$ & $\begin{array}{l}\text { Retrograde IFT } \\
\text { motor }\end{array}$ & $\begin{array}{l}\text { Partial loss of ventral neural cell types; } \\
\text { polydactyly; midgestation lethality } \\
\text { (Huangfu and Anderson 2005; May et al. } \\
\text { 2005) }\end{array}$ & $\begin{array}{l}\text { Short rib dysplasia, with or } \\
\text { without polydactyly } \\
\text { (SRP) (Dagoneau et al. } \\
\text { 2009; Merrill et al. 2009) }\end{array}$ \\
\hline $\begin{array}{l}\text { Dync2li1 } \\
\text { (D2lic) }\end{array}$ & $\begin{array}{l}\text { Dynein light } \\
\text { intermediate } \\
\text { chain }\end{array}$ & & $\begin{array}{l}\text { SRP (Taylor et al. 2015), } \\
\text { Jeune syndrome (JATD) } \\
\quad \text { (Kessler et al. 2015) }\end{array}$ \\
\hline$W d r 34$ & Dynein light chain & & SRP (Huber et al. 2013) \\
\hline Tctex $1 d 2$ & $\begin{array}{l}\text { Light chain, IFT } \\
\text { dynein }\end{array}$ & & Jeune syndrome \\
\hline $\begin{array}{l}\text { Ift } 25 \\
\qquad(H s p b 11)\end{array}$ & IFT-B & $\begin{array}{l}\text { Perinatal lethality; weak loss of ventral } \\
\text { neural cell types; partially penetrant } \\
\text { polydactyly (Keady et al. 2012) }\end{array}$ & \\
\hline Ift 27 & IFT-B & $\begin{array}{l}\text { Perinatal lethality; weak loss of ventral } \\
\text { neural cell types; partially penetrant } \\
\text { polydactyly (Eguether et al. 2014) }\end{array}$ & \\
\hline $\begin{array}{l}\text { Ift38 } \\
\quad \text { (Cluap1) }\end{array}$ & IFT-B & $\begin{array}{l}\text { Midgestation lethality; abnormal neural } \\
\text { patterning (Botilde et al. 2013) }\end{array}$ & \\
\hline Ift52 & IFT-B & $\begin{array}{l}\text { Loss of SHH-dependent ventral neural cell } \\
\text { types; midgestation lethality; } \\
\text { polydactyly (Liu et al. 2005) }\end{array}$ & \\
\hline $\begin{array}{l}\text { Ift54 } \\
\quad(\text { Traf3ip1) }\end{array}$ & IFT-B & $\begin{array}{l}\text { Loss of SHH-dependent ventral neural cell } \\
\text { types; midgestation lethality; } \\
\text { polydactyly (Berbari et al. 2011) }\end{array}$ & $\begin{array}{l}\text { Senior-Løken syndrome } \\
\quad \text { (Bizet et al. 2015) }\end{array}$ \\
\hline Ift57 (Hippi) & IFT-B & $\begin{array}{l}\text { Loss of SHH-dependent ventral neural cell } \\
\text { types; midgestation lethality; } \\
\text { polydactyly (Houde et al. 2006) }\end{array}$ & \\
\hline $\begin{array}{l}\text { Ift } 80 \\
\qquad(\text { WDR56) }\end{array}$ & IFT-B & $\begin{array}{l}\text { Hypomorphic allele only: short long bones; } \\
\text { polydactyly; late gestation lethality (Rix } \\
\text { et al. 2011) }\end{array}$ & SRP, JATD \\
\hline $\begin{array}{l}\text { IftT88 } \\
\qquad \text { (Polaris; } \\
\quad \text { Tg737) }\end{array}$ & IFT-B & $\begin{array}{l}\text { Loss of SHH-dependent ventral neural cell } \\
\text { types; midgestation lethality; } \\
\text { polydactyly (Huangfu et al. 2003) }\end{array}$ & \\
\hline Ift172 & IFT-B & $\begin{array}{l}\text { Loss of SHH-dependent ventral neural cell } \\
\text { types; midgestation lethality (Huangfu } \\
\text { et al. 2003) }\end{array}$ & Jeune (Halbritter et al. 2013) \\
\hline Ttc26 (hop) & IFT-B & $\begin{array}{l}\text { Partial loss of function allele only; } \\
\text { abnormal neural patterning (Swiderski } \\
\text { et al. 2014) }\end{array}$ & \\
\hline $\begin{array}{l}\text { Ift121 } \\
\qquad(W d r 35)\end{array}$ & IFT-A & Polydactyly (Mill et al. 2011) & $\begin{array}{l}\text { SRP (Mill et al. 2011); Ellis- } \\
\text { van Creveld (EVC) } \\
\text { syndrome (Caparrós- } \\
\text { Martín et al. 2015) }\end{array}$ \\
\hline
\end{tabular}

Continued 
F. Bangs and K.V. Anderson

Table 1. Continued

\begin{tabular}{|c|c|c|c|}
\hline Mouse gene & Function in cilia & $\begin{array}{l}\text { Mouse embryo Hh pathway null phenotype } \\
\text { (neural and limb) }\end{array}$ & Human phenotype \\
\hline Ift 122 & IFT-A & $\begin{array}{l}\text { Expansion of SHH-dependent ventral } \\
\text { neural cell types; midgestation lethality; } \\
\text { polydactyly (Qin et al. 2011) }\end{array}$ & $\begin{array}{l}\text { Sensenbrenner syndrome } \\
\text { (Walczak-Sztulpa et al. } \\
\text { 2010) }\end{array}$ \\
\hline $\begin{array}{l}\text { Ift139 } \\
\qquad \begin{array}{l}\text { (Ttc21b/ } \\
\text { Thm1/ } \\
\text { alien) }\end{array}\end{array}$ & IFT-A & $\begin{array}{l}\text { Expansion of SHH-dependent ventral } \\
\text { neural cell types; late gestation lethality; } \\
\text { polydactyly (Tran et al. 2008) }\end{array}$ & $\begin{array}{l}\text { NPHP12, JATD/SRP (Davis } \\
\text { et al. 2011) }\end{array}$ \\
\hline Ift140 & IFT-A & $\begin{array}{l}\text { Polydactyly, neural tube closure defects, } \\
\text { (Miller et al. 2013) }\end{array}$ & SRTD9 (Perrault et al. 2012) \\
\hline $\begin{array}{l}\text { Ift144 } \\
\qquad(W d r 19)\end{array}$ & IFT-A & $\begin{array}{l}\text { Weak allele: GOF neural; polydactyly. } \\
\text { Strong allele: LOF (Liem et al. 2012) } \\
\text { (Wicking) }\end{array}$ & $\begin{array}{l}\text { Various: Senior-Løken, } \\
\text { Sensenbrenner, Jeune, } \\
\text { NPHP, RP (Bredrup et al. } \\
\text { 2011; Fehrenbach et al. } \\
\text { 2014) }\end{array}$ \\
\hline Tulp3 & IFT-A-associated & $\begin{array}{l}\text { Expansion of SHH-dependent ventral } \\
\text { neural cell types; midgestation lethality; } \\
\text { polydactyly (Norman et al. 2009; } \\
\text { Patterson et al. 2009) }\end{array}$ & \\
\hline Gpr161 & GPCR & $\begin{array}{l}\text { Expansion of SHH-dependent ventral } \\
\text { neural cell types; midgestation lethality } \\
\text { (Mukhopadhyay et al. 2013) }\end{array}$ & \\
\hline $\begin{array}{l}\text { C2cd3 (chick } \\
\text { talpid2) }\end{array}$ & $\begin{array}{l}\text { Distal appendage } \\
\text { protein }\end{array}$ & $\begin{array}{l}\text { Loss of SHH-dependent ventral neural cell } \\
\text { types; midgestation lethality; } \\
\text { polydactyly (Hoover et al. 2008; Ye et al. } \\
\text { 2014) }\end{array}$ & $\begin{array}{l}\text { Skeletal dysplasia (Cortés } \\
\text { et al. 2016) }\end{array}$ \\
\hline Ofd1 & $\begin{array}{l}\text { Centriole and } \\
\text { centriolar satellites }\end{array}$ & $\begin{array}{l}\text { Loss of SHH-dependent ventral neural cell } \\
\text { types; midgestation lethality (Ferrante } \\
\text { et al. 2006) }\end{array}$ & $\begin{array}{l}\text { Oral-facial-digital syndrome } \\
\quad \text { (Ferrante et al. 2001) }\end{array}$ \\
\hline$T t b k 2$ & $\begin{array}{l}\text { Kinase required for } \\
\text { cilia initiation; } \\
\text { associates with } \\
\text { distal appendages }\end{array}$ & $\begin{array}{l}\text { Loss of SHH-dependent ventral neural cell } \\
\text { types; midgestation lethality (Goetz et al. } \\
\text { 2012) }\end{array}$ & $\begin{array}{l}\text { Spinocerebellar ataxia type } \\
11 \text { (Houlden et al. 2007) }\end{array}$ \\
\hline Talpid3 & $\begin{array}{l}\text { Associated with } \\
\text { distal appendages } \\
\text { and PCM }\end{array}$ & $\begin{array}{l}\text { Loss of SHH-dependent ventral neural cell } \\
\text { types; midgestation lethality; } \\
\text { polydactyly (Bangs et al. 2011) }\end{array}$ & $\begin{array}{l}\text { Ciliopathy spectrum (Alby } \\
\text { et al. 2015); Joubert } \\
\text { syndrome (Stephen et al. } \\
\text { 2015) }\end{array}$ \\
\hline Inpp5e & $\begin{array}{l}\text { Cilia membrane } \\
\text { composition }\end{array}$ & Bielas et al. 2009; Jacoby et al. 2009 & $\begin{array}{l}\text { Joubert syndrome (JBTS1) } \\
\text { (Bielas et al. 2009); } \\
\text { MORM syndrome } \\
\text { (Jacoby et al. 2009) }\end{array}$ \\
\hline Rab23 & Not clear & $\begin{array}{l}\text { GOF neural; polydactyly (Eggenschwiler } \\
\text { et al. 2001) }\end{array}$ & $\begin{array}{l}\text { Carpenter syndrome } \\
\text { (Jenkins et al. 2007) }\end{array}$ \\
\hline Kif7 & $\begin{array}{l}\text { Kinesin- } 4 \text { protein; } \\
\text { controls dynamics } \\
\text { of axonemal } \\
\text { microtubules }\end{array}$ & $\begin{array}{l}\text { Mild expansion of SHH-dependent ventral } \\
\text { neural cell types; polydactyly, defective } \\
\text { diaphragm (Cheung et al. 2009; Endoh- } \\
\text { Yamagami et al. 2009; Liem et al. 2009; } \\
\text { Coles and Ackerman 2013; He et al. } \\
\text { 2014) }\end{array}$ & $\begin{array}{l}\text { Joubert syndrome; } \\
\text { acrocallosal syndrome }\end{array}$ \\
\hline
\end{tabular}


Table 1. Continued

\begin{tabular}{|c|c|c|c|}
\hline Mouse gene & Function in cilia & $\begin{array}{l}\text { Mouse embryo Hh pathway null phenotype } \\
\text { (neural and limb) }\end{array}$ & Human phenotype \\
\hline $\begin{array}{l}\text { Tectonic } \\
\quad(\text { Tctn1) }\end{array}$ & $\begin{array}{l}\text { Transition zone } \\
\text { protein }\end{array}$ & $\begin{array}{l}\text { Abnormal patterning of SHH-dependent } \\
\text { ventral neural cell types (Reiter and } \\
\text { Skarnes 2006) }\end{array}$ & $\begin{array}{l}\text { Joubert (Garcia-Gonzalo } \\
\text { et al. 2011) }\end{array}$ \\
\hline$M k s 1$ & $\begin{array}{l}\text { Transition zone } \\
\text { protein }\end{array}$ & $\begin{array}{l}\text { Abnormal patterning of SHH-dependent } \\
\text { ventral neural cell types (Weatherbee } \\
\text { et al. 2009) }\end{array}$ & $\begin{array}{l}\text { Meckel syndrome (Kyttälä } \\
\text { et al. 2006) }\end{array}$ \\
\hline Fuzzy & CPLANE complex & $\begin{array}{l}\text { Loss of SHH-dependent ventral neural cell } \\
\text { types; late gestation lethality; polydactyly } \\
\text { (Heydeck et al. 2009) }\end{array}$ & \\
\hline Inturned & CPLANE complex & $\begin{array}{l}\text { Loss of SHH-dependent ventral neural cell } \\
\text { types; late gestation lethality; polydactyly } \\
\text { (Zeng et al. 2010) }\end{array}$ & \\
\hline Jbts17 & CPLANE complex & $\begin{array}{l}\text { Skeletal and heart defects; no change in } \\
\text { neural patterning detected (Damerla } \\
\text { et al. 2015) }\end{array}$ & $\begin{array}{l}\text { Joubert syndrome (Srour } \\
\text { et al. 2012) }\end{array}$ \\
\hline Rsg1 & $\begin{array}{l}\text { Small GTPase, } \\
\text { CPLANE- } \\
\text { associated }\end{array}$ & $\begin{array}{l}\text { Loss of SHH-dependent ventral neural cell } \\
\text { types; late gestation lethality; polydactyly } \\
\text { (S Agbu and KV Anderson, in prep.) }\end{array}$ & \\
\hline$E v c 1 / E v c 2$ & $\begin{array}{l}\text { Ciliary membrane } \\
\text { protein }\end{array}$ & $\begin{array}{l}\text { EVC-like (Ruiz-Perez et al. 2007; Caparrós- } \\
\text { Martín et al. 2013) }\end{array}$ & $\begin{array}{l}\text { Ellis-van Creveld syndrome } \\
\text { (Ruiz-Perez et al. 2003) }\end{array}$ \\
\hline Arl13b & $\begin{array}{l}\text { Ciliary membrane } \\
\text { GTPase }\end{array}$ & $\begin{array}{l}\text { Loss of both the most dorsal and most } \\
\text { ventral neural cell types (Caspary et al. } \\
\text { 2007) }\end{array}$ & $\begin{array}{l}\text { Joubert syndrome } \\
\quad \text { (Cantagrel et al. 2008) }\end{array}$ \\
\hline $\begin{array}{l}\text { Sas-4 (p53) } \\
\text { (Cpap/ } \\
\text { Cenpj) }\end{array}$ & $\begin{array}{l}\text { Centriole } \\
\text { duplication }\end{array}$ & $\begin{array}{l}\text { Loss of SHH-dependent ventral neural cell } \\
\text { types; midgestation lethality (Bazzi and } \\
\text { Anderson 2014) }\end{array}$ & $\begin{array}{l}\text { Microcephaly (Bond et al. } \\
\text { 2005) }\end{array}$ \\
\hline $\begin{array}{l}\text { DZip1/ } \\
\text { Iguana }\end{array}$ & Cilia base & $\begin{array}{l}\text { Loss of SHH-dependent ventral neural cell } \\
\text { types; midgestation lethality (Wang et al. } \\
\text { 2013) }\end{array}$ & \\
\hline
\end{tabular}

References noted in table are for specific mouse and human proteins and phenotypes. This is not a complete list of references, and includes only the earliest mouse references, and is not a complete list of phenotypes.

IFT, intraflagellar transport; GPCR, G-protein-coupled receptor; PCM, pericentriolar material; CPLANE, ciliogenesis and planar polarity effector; SHH, Sonic Hedgehog; GOF, gain of function; LOF, loss of function; MORM, mental retardation, truncal obesity, retinal dystrophy, and micropenis.

lack both Ptch1 and Ift172 lack all ventral neural cell types, like the Ift172 single mutants (Fig. 2) (Huangfu et al. 2003). Thus, the ectopic activation of the Hh pathway caused by loss of Ptch1 depends on IFT172, arguing that IFT is required at a step in the signal transduction pathway downstream from PTCH1. Similar double mutant analysis showed that IFT172, IFT88, and KIF3A act downstream from both PTCH1 and SMO and upstream of the GLI proteins, at the heart of the signal transduction cascade (Fig. 1).

\section{CENTRIOLE AND BASAL BODY PROTEINS ARE ALSO REQUIRED FOR THE RESPONSE TO Hh}

In addition to IFT proteins, other proteins that build cilia are also required for the ability of cells to respond to Hh family ligands (Table 1). The doublet microtubules of the cilium are templated by the triplet microtubules of the mother centriole. Embryos that lack centrioles because of the lack of proteins required for centriole duplication, such as SAS4 (CPAP/CENPJ), 
can go through normal segregation at mitosis but fail to assemble cilia. These embryos can survive to midgestation (if a cell-cycle checkpoint is blocked by removal of p53) but Shhdependent ventral neural cell types are not specified (Bazzi and Anderson 2014). The distal appendages of the mother centriole are required for docking on the plasma membrane (Tanos et al. 2013). The distal appendage protein $\mathrm{C} 2 \mathrm{~cd} 3$ is required for the centriole to dock on the ciliary vesicle (Ye et al. 2014) and $C 2 c d 3$ null mutant embryos lack cilia and lack Hh-dependent ventral neural cell types (Hoover et al. 2008). Talpid 3 and OFD1 are both centrosome-associated proteins required for ciliogenesis and for the response to SHH in the neural tube (Ferrante et al. 2006; Bangs et al. 2011). Tau tubulin kinase 2 (TTBK2) is required for cilia initiation and mutants lack all cilia and Hh-dependent ventral neural cell types (Goetz et al. 2012). Embryos that lack CP110, a protein that localizes to the distal ends of mother centrioles, also have fewer cilia and mild defects in $\mathrm{Hh}$ signaling (Yadav et al. 2016).

The CPLANE (ciliogenesis and planar polarity effector) protein complex is located at the basal body and includes downstream mediators of planar cell polarity in Drosophila, Fuzzy, Inturned, and Fritz (Wdpcp), and Jbts17, a gene responsible for Joubert syndrome in humans (Damerla et al. 2015; Toriyama et al. 2016). The CPLANE complex is required for efficient ciliogenesis as it functions to recruit IFT-A proteins to the cilium RSG1, a small GTPase that appears to be a peripheral member of the CPLANE complex. Rsg1 mutant mice have fewer cilia of normal morphology, suggesting Rsg1 has a specific role in cilia initiation (S Agbu and KVAnderson, in prep.). These mutants survive longer than IFT-B mutants, yet still display $\mathrm{Hh}$ signaling defects. Thus, diverse classes of proteins are required to build cilia and ensure efficient ciliogenesis. Loss of any type of protein required for normal cilia formation in the mouse prevents or attenuates cells from responding to Shh. Thus, it is the primary cilium, rather than another activity of the IFT machinery, which is required for mammalian cells to respond to Hh ligands.
CILIA ARE REQUIRED FOR RESPONSES TO Hh FAMILY LIGANDS IN ALL VERTEBRATE TISSUES

Conditional genetic deletion of Ift88 and/or Kif $3 a$ has been used to test the role of cilia in Hh signaling in other mouse tissues. In every context examined, removal of cilia blocks the response to both $\mathrm{SHH}$ and $\mathrm{IHH}$ (Table 2). The defects observed include shortened bones of the limb, craniofacial defects, and loss of neural stem and progenitor cells.

Cilia are also required for $\mathrm{Hh}$ signaling in other vertebrates. As in the mouse, absence of cilia in the chick blocks the ability of cells to receive Hh signals (Yin et al. 2009). In zebrafish, loss of cilia leads to milder defects in Hh-dependent patterning, in part because of the maternal contribution of cilia proteins or mRNAs to the zebrafish embryo, which masks the phenotype in homozygous embryos, and in part because of the different roles of the zebrafish GLI proteins in Hh responses (Huang and Schier 2009; Tay et al. 2010; Ben et al. 2011).

In humans, it is not possible to directly examine the requirement of cilia for Hh signaling during development, as mutations that completely disrupt IFT genes would presumably result in lethality in the first half of gestation, as in mice, and would not be detected. However, many mutations in human cilia genes do not completely ablate cilia, allowing survival to the end of gestation with comparatively mild Hh pathway defects (Table 1). For example, mutations in the cytoplasmic dynein-2 complex cause short ribs (narrow chest) - short-rib dysplasia, with or without polydactyly (SRP) or Jeune asphyxiating thoracic dystrophy (JATD) (Dagoneau et al. 2009; Merrill et al. 2009).

Further evidence that cilia are important for Hh signaling in humans comes from their impact on two human tumor types, medulloblastoma and basal cell carcinoma, which are both caused by gain of Hh signaling. In mouse medulloblastoma or basal cell carcinoma triggered by activated SMO, conditional removal of cilia blocks tumor formation, consistent with the requirement for cilia at a step downstream from SMO. The same tumors can also be caused by 
Cilia and Hedgehog Signaling

Table 2. In every context examined, removal of cilia blocks the response to both $\mathrm{SHH}$ and IHH

\begin{tabular}{|c|c|c|c|}
\hline Tissue & $\begin{array}{l}\text { Conditional } \\
\text { allele }\end{array}$ & Cre & Phenotype \\
\hline Cranial neural crest & Kif3a & Wnt1 & Craniofacial defects (Liu et al. 2014) \\
\hline $\begin{array}{l}\text { Endochondral bone (Ihh- } \\
\text { dependent) }\end{array}$ & Ift 88 & $\operatorname{Prx} 1$ & Short bones (Haycraft et al. 2007) \\
\hline Postnatal cartilage & Kif3a & Col2a1-Cre & Craniofacial defects (Koyama et al. 2007) \\
\hline Neural stem cells & Kif3a & $h G F A P$ & Loss of hippocampal stem cells (Han et al. 2008) \\
\hline Hippocampal stem cells & Ift 20 & $m G F A P$ & $\begin{array}{l}\text { Reduction hippocampal amplifying progenitors } \\
\text { (Amador-Arjona et al. 2011) }\end{array}$ \\
\hline $\begin{array}{l}\text { Postnatal B1 SVZ neural } \\
\text { stem cells }\end{array}$ & Kif3a & $\begin{array}{l}\text { Adeno-Cre } \\
\quad \text { (injected) }\end{array}$ & $\begin{array}{l}\text { Decreased proliferation of neural stem cells (Tong et al. } \\
\text { 2014) }\end{array}$ \\
\hline $\begin{array}{l}\text { Cerebellar granule cell } \\
\text { precursors }\end{array}$ & Kif3a & $h G F A P$ & $\begin{array}{l}\text { Loss of cerebellar granule cell progenitors (Chizhikov } \\
\text { et al. 2007; Spassky et al. 2008) }\end{array}$ \\
\hline Basal cell carcinoma & Kif $3 a ;$ Ift 88 & Keratin14 & $\begin{array}{l}\text { Removal of cilia inhibited tumors induced by activated } \\
\text { Smoothened. Removal of cilia accelerated tumors } \\
\text { induced by activated Gli2 (Wong et al. 2009) }\end{array}$ \\
\hline Medulloblastoma & Kif $3 a$ & hGFAP & $\begin{array}{l}\text { Removal of cilia inhibited tumors induced by activated } \\
\text { Smoothened. Removal of cilia accelerated tumors } \\
\text { induced by activated Gli2 (Han et al. 2009) }\end{array}$ \\
\hline
\end{tabular}

SHH, Sonic Hedgehog; IHH, Indian Hedgehog; SVZ, subventricular zone.

activation of GLI2; in these cases, removal of cilia makes the tumors more aggressive because GLI3 repressor is no longer generated resulting in a greater net GLI activation.

\section{TRAFFICKING OF PATHWAY PROTEINS WITHIN THE CILIUM IS REQUIRED FOR Hh SIGNALING}

Immunolocalization experiments showed that all the proteins required for transduction of Hh signals are enriched in primary cilia and change their distribution in response to ligand (Fig. 3). The first demonstration of cilia localization came for the membrane protein SMO, which accumulates in the cilium within an hour following stimulation of the Hh pathway (Corbit et al. 2005; Rohatgi et al. 2007). As total SMO protein levels are unaltered, accumulation of SMO in the cilium is a consequence of translocation of a ready-made pool of SMO and not from newly synthesized protein (Rohatgi et al. 2007). A common hydrophobic and basic residue motif following the seventh transmembrane domain at the carboxyl terminus of $\mathrm{SMO}$ is required for localization of SMO to the cilium in the presence of $\mathrm{SHH}$ (Händel et al. 1999; Brailov et al. 2000; Dwyer et al. 2001; Corbit et al. 2005; Aanstad et al. 2009). Single-molecule imaging indicates that once in the cilium SMO moves by diffusion within the membrane, rather than by IFT (Milenkovic et al. 2015). Localization of SMO to the cilium is, however, not sufficient for signaling, as SMO accumulates in primary cilia that lack Dync $2 \mathrm{~h} 1$, the heavy change of the retrograde dynein IFT motor, but Dync $2 h 1$ mutants lack ventral neural cell types (Huangfu and Anderson 2005; May et al. 2005).

Even more remarkable, all three transcription factors of the GLI family, the mediators of Hh-regulated transcription, are enriched at cilia tips in the absence of Hh ligand and become further enriched in response to pathway activation (Haycraft et al. 2005). Only full-length GLI proteins localize to cilia, whereas the proteolytically processed repressor forms that lack the carboxy-terminal half of the protein do not (Wen et al. 2010; Santos and Reiter 2014). Deletion analysis identified a 330-amino-acid (out of the 1544 in the full-length protein) central region of GLI2 is required for cilia targeting. SUFU, a key negative regulator of vertebrate Hh signaling, binds to GLI preventing its acti- 
F. Bangs and K.V. Anderson
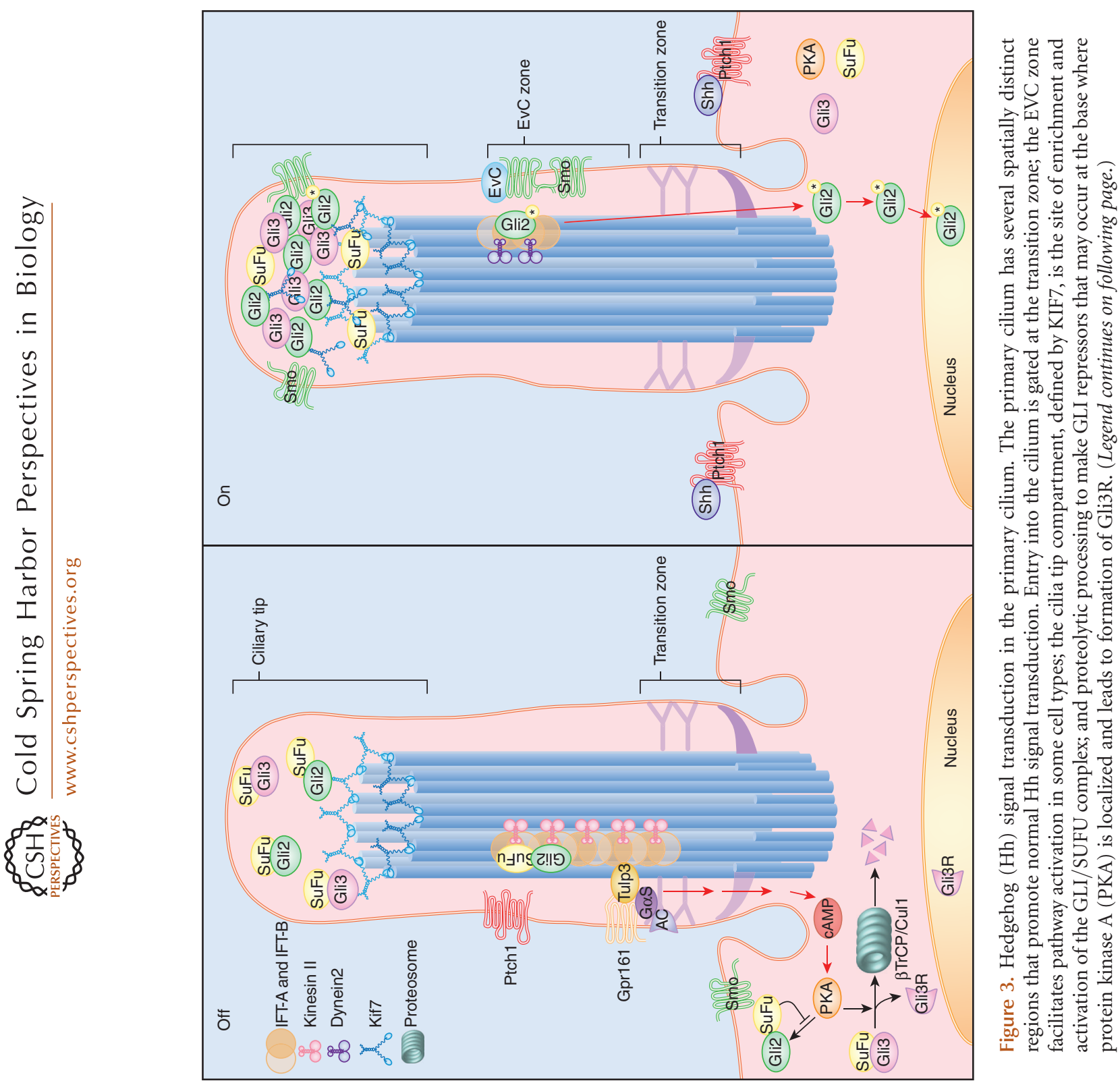
vation and is also highly enriched at cilia tips (Haycraft et al. 2005).

PTCH1 has 12 transmembrane domains and the region carboxy-terminal to the last transmembrane domain is required for cilia localization and signaling (Kim et al. 2015). PTCH1 is localized to cilia in the absence of ligand and binding of $\mathrm{SHH}$ to PTCH1 triggers its removal from the cilium, although removal of PTCH1 from the cilium is not required for Hh pathway activation. During the same interval after exposure to ligand when PTCH moves out of the cilium, SMO translocates into the cilium (Rohatgi et al. 2007).

\section{CILIA ARE REQUIRED FOR BOTH KEEPING THE PATHWAY OFF AND TURNING THE PATHWAY ON}

In mammals, the GLI family of transcription factors, GLI1, GLI2, and GLI3 implement the transcriptional responses to Hh family ligands (Bai et al. 2004). In the absence of ligand, proteolytically processed forms of GLI proteins repress expression of Hh target genes (primarily GLI3, with a minor role for GLI2). In the presence of ligand, processing of the repressor forms is blocked and, instead, full-length GLI proteins are converted (by an unknown mechanism) to GLI activators, principally mediated by GLI2. The formation of both GLI repressor and activator depend on cilia (Huangfu and Anderson 2005; Liu et al. 2005; May et al. 2005).

Proteolytic processing of the GLI proteins depends on phosphorylation by cAMP-dependent PKA, a key evolutionarily conserved com- ponent of the Hh signal transduction pathway (Wang et al. 2014). In contrast to Drosophila, mammalian PKA does not act only by promoting formation of GLI repressor, it is also required to prevent inappropriate activation of GLI2 (Tuson et al. 2011). In addition to the phosphorylation sites on GLI2 required for proteolytic processing, phosphorylation of two additional PKA sites of GLI2 and GLI3 prevents formation of the fully activated form of the transcription factors (Niewiadomski et al. 2014).

Both the catalytic and regulator subunits of PKA are highly enriched at the base of the cilium (Barzi et al. 2010; Tuson et al. 2011). Mutant mouse embryos that lack both genes that encode catalytic subunits ( $P K A$ nulls) show a very strong activation of the $\mathrm{Hh}$ pathway, in which all cells in the neural tube acquire the most ventral fates (Tuson et al. 2011). Compound mutants that lack both PKA catalytic subunits and also lack cilia have a neural phenotype similar to cilia mutants, showing that the action of PKA depends on events that take place in cilia. Although both catalytic and regulatory subunits of PKA are highly enriched at the base of the cilium, recent proximity ligation experiments provide biochemical evidence that regulatory subunits of PKA localize to the cilium (Mick et al. 2015), suggesting that sensing of cAMP by PKA may take place inside cilia.

PKA is activated by cAMP, and several adenylyl cyclases that produce cAMP, including AC3, AC5, and AC6, are enriched in cilia (Bishop et al. 2007; Mick et al. 2015; Vuolo et al. 2015). These, in turn, are regulated by G-protein-coupled receptors (GPCRs), including

Figure 3. (Continued) In the absence of Hh signal, PTCH1 and Gpr161, both negative regulators of the pathway, are present in the cilia membrane. Gpr161 trafficking into the cilium depends on TULP 3 and intraflagellar transport (IFT)-A; GPR161 appears to activate Gos, which activates adenylyl cyclase, which increases the levels of cAMP, thereby activating PKA. Activated PKA phosphorylates sites on GLI3 that promote partial proteolysis by $\beta \operatorname{TrCP} / \mathrm{Cul}$ and the proteasome, generating Gli3 repressor (Gli3R), which moves to the nucleus and represses expression of Hh target genes. GLI2 and GLI3 are trafficked to the tip of the cilium in the absence of ligand in a complex with SuFu, and processing of GLI3 depends on it having transited the cilium. Binding of Hh to PTCH1 triggers its removal from the cilium, allowing Smoothened (SMO) to translocate into the cilium where it can activate downstream signaling. Gpr161 also exits the cilium after exposure to ligand. Binding of EvC to SMO near the base of the cilium promotes SMO activity. In the presence of ligand, the GLI/SUFU complex accumulates to high levels at the tip of the cilium, where dissociation of the complex allows formation of the activator form of GLI2. 
Gpr161, which activates ACIII and thereby increases cAMP levels (Mukhopadhyay et al. 2013). Like PTCH1, Gpr161 is present in the cilia membrane in the absence of ligand and moves out of the cilium in response to ligand. This movement is regulated by TULP 3 , a member of the vertebrate tubby-like family of proteins, which links GPCRs, including Gpr161, to IFT-A, which transports them into the cilium (Nishina et al. 1998; Mukhopadhyay et al. 2010).

Small G proteins, including Gas, mediate the actions of GPCRs. In mouse embryos that lack Gos (Gnas), the Hh pathway is ectopically activated with a phenotype similar to that of PKA or Ptch1 mutant embryos, indicating that Gos negatively regulates the Hh pathway (Regard et al. 2013). Thus, the Hh pathway is kept off in the absence of ligand by Gpr161, which is localized to the cilium by TULP 3 and activated by Gas. Gpr161 subsequently activates adenylyl cyclase, leading to increased cAMP and increased PKA activity, which promotes GLI repressor formation and prevents GLI activation (Fig. 3) (Mukhopadhyay and Rohatgi 2014).

\section{CHANGES IN AXONEMAL STRUCTURE OR CILIA MEMBRANE COMPOSITION CAN INCREASE OR DECREASE Hh PATHWAY ACTIVITY}

The requirement for primary cilia for Hh signaling and the localization of pathway proteins to the cilium would be consistent with the cilium acting as a scaffold for Hh signal transduction or a site for concentration of Hh pathway proteins. However, subtle changes in cilia structure can decrease or increase Hh pathway activity, suggesting that the cilium provides more than just a permissive context for Hh signaling. (References to specific mouse and human proteins and phenotypes are in Table 1.)

Embryos carrying mutations in the gene that encodes the heavy chain of the retrograde motor cytoplasmic dynein 2 (Dync2hl) assemble cilia; however, the axoneme is bulged because of accumulation of IFT complexes and other proteins trapped in the cilium as a consequence of defective retrograde transport. Like IFT-B or Kif3a mutant embryos, Dync2hl mu- tants lack floor plate and V3 interneuron progenitors indicating these cells cannot respond to high levels of Shh signaling. However, unlike IFT-B or Kif $3 a$ mutants, motor neurons are specified in the caudal spinal cord of Dync2hl mutants in which they are intermingled with V2 interneurons (Fig. 2) (Huangfu and Anderson 2005; May et al. 2005). Thus, low levels of $\mathrm{Hh}$ signaling can still be transduced in the bulged Dync2h1 cilia.

Although null mutations in most IFT-B components block cilia formation, abnormal cilia form in most mutants that lack one of the six proteins of the IFT-A complex. Mutations that strongly disrupt the mouse IFT-A proteins IFT122 or IFT139 cause bulged cilia, similar to mutants that lack Dynein2. However, unlike mutants that disrupt Dynein2, the IFT-A mutants show a gain-of-activity of the Hh pathway in the neural tube, with expanded domains of Shh-dependent ventral neuron cell types (e.g., motor neurons) (Fig. 2) (Tran et al. 2008; Qin et al. 2011). This gain-of-function for Hh pathway activity is independent of ligand, suggesting that IFT-A plays a specific role in keeping the pathway off in the absence of ligand. A similar phenotype is seen in embryos that lack TULP3 (Mukhopadhyay et al. 2010).

The effects of mutations in IFT-A genes on Hh signaling are complex. Aweak allele of Ift144 (WDR19) shows bulged cilia and ventralization of the neural tube similar to that seen in IFT122 or 139 (Table 1). However, a stronger allele that produces only very short bloated cilia with a highly disrupted axoneme causes a loss of $\mathrm{Hh}$ signaling in the neural tube. Double mutants that carry both the weak allele of Ift144 and an allele of Ift122 show the short bulged cilia and loss-of-function Hh neural phenotype, suggesting that some IFT-A proteins have overlapping functions and that a complete lack of IFT-A complex activity leads to the formation of very short cilia and a loss of Hh activity (Liem et al. 2012). Human mutations in IFT-A genes cause a spectrum of phenotypes, ranging in severity from retinitis pigmentosum in the adult to SRP associated with perinatal lethality (Table 1).

Even small changes in IFT function can have subtle effects on Hh signaling activity. IFT25 
and IFT27 form an IFT-B subcomplex. In contrast to other IFT-B proteins, mutants that lack either of these proteins make primary cilia that have apparently normal structure. The mouse mutants survive to birth, when they show mild $\mathrm{Hh}$ pathway phenotypes and defects in trafficking of GLI2, SMO, and PTCH1. IFT27 appears to be important for loading of retrograde IFT cargo in trypanosomes (Huet et al. 2014), and given the evolutionary conservation of IFT proteins, it is likely that the Hh defects in mouse Ift25 and Ift27 mutants are the result of relatively subtle changes in global IFT. This indicates that Hh signaling is sensitive to even small changes in IFT function.

ARL13B is an ARF-family GTPase that is a component of the ciliary membrane that is required for normal cilia structure-in the absence of ARL13B, cilia are short and the B-tubules of the axoneme are frequently open. The neural tube of $A r l 13 b$ mouse mutants lacks both the most ventral and the most dorsal cell types, indicating that when ciliary structure is disrupted in this way it is not possible to achieve the highest level of Hh signaling or to prevent ectopic low-level activation of the pathway.

It has been supposed that cilia length affects Hh signaling; however, it appears not to be the case. Cilia on $R f \times 3$ mutant cells are about half the normal length (Bonnafe et al. 2004) and embryos that overexpress ARL13B have cilia that are 50\% longer than wild-type (Bangs et al. 2015), but both genotypes are viable and apparently have a normal pattern of Hh-dependent neural cell types.

The ciliary membrane has a distinct lipid composition; the inositol phosphate $\mathrm{PI}(4) \mathrm{P}$ is enriched in the entire ciliary membrane and $\mathrm{PI}(4,5) \mathrm{P}_{2}$ is enriched at the base of the cilium. Inpp5e, a ciliary phosphoinositide 5-phosphatase, is required to maintain this distribution and is one of the genes mutated in Joubert syndrome (Chávez et al. 2015; Garcia-Gonzalo et al. 2015). In Inpp5e mutant mice, ciliary $\mathrm{PI}(4,5) \mathrm{P}_{2}$ levels are elevated, causing disrupted Hh signaling, apparently a result of inappropriate accumulation of TULP3, which binds to these phosphoinositides. Inpp5e mutant mice survive to birth when they show polydactyly, suggesting that they have a significant, but relatively mild disruption of Hh signal transduction.

\section{KIF7 ORGANIZES THE CILIA TIP COMPARTMENT}

One rationale for why Hh signaling requires the primary cilium is that it concentrates components of the Hh signal transduction cascade in a small volume, promoting their interactions by mass action. It has been calculated that concentrating the entire pool of a protein into the cilium would increase its concentration by two to three orders of magnitude (Nachury 2014). However, certain $\mathrm{Hh}$ components, GLI, SuFu, and KIF7, are strongly enriched at the cilia tip. Full-length Gli proteins form complexes with $\mathrm{SuFu}$, and data indicate that separation of $\mathrm{SuFu}$ and GLI proteins is critical for GLI activation (Humke et al. 2010); it is likely that this separation occurs or is regulated by events that happen at the tip of the cilium. KIF7 also binds directly to both GLI2 and GLI3 (Cheung et al. 2009; Endoh-Yamagami et al. 2009).

The tip compartment of the primary cilium is organized, at least in part, by KIF7, an evolutionarily conserved core component of the $\mathrm{Hh}$ pathway (He et al. 2014). KIF7 and its Drosophila homolog Cos 2 have both positive and negative roles in Hh signal transduction. KIF7, a member of the Kinesin-4 family, binds microtubule plus-ends at the tip of the cilium to organize microtubule architecture at the tip ( $\mathrm{He}$ et al. 2014). In the absence of KIF7, axonemal microtubules have variable lengths, and GLI and $\mathrm{SuFu}$ are localized in multiple puncta along the ciliary axoneme that appear to correspond to ectopic cilia tip compartments. The mislocalization of the GLI/SUFU complex causes inappropriate, ligand-independent GLI activation and the mild ectopic activation of the pathway seen in $\mathrm{Kif7}^{-/-}$mutant embryos.

\section{CELL-TYPE-SPECIFIC DIFFERENCES IN CILIA COMPOSITION CAN MODULATE Hh SIGNALING}

Most proteins that have a role in Hh signaling in the cilium act in all cell types. Two exceptions 
are EVC and EVC2, transmembrane proteins responsible for Ellis-van Creveld syndrome, a distinctive ciliopathy associated with short limbs, a narrow chest (short ribs), and polydactyly (Ruiz-Perez et al. 2003). Mouse Evc is highly expressed in differentiating chondrocytes and all the cartilaginous components of the skeleton. Evc mutant mice survive to birth, and some can survive to adulthood; like the affected people, the mice have short bones, short ribs, and abnormal teeth, although the response to Shh in the neural tube appears to be nearly normal (Caparrós-Martín et al. 2013). Specific partial loss-of-function mutations that disrupt the IFT-A protein IFT121/ WDR35 also cause EVC syndrome, and both EVC proteins and SMO fail to localize to Ift121/Wdr35 mutant MEF cilia (CaparrósMartín et al. 2015). As other IFT-A proteins are also required for the recruitment of transmembrane proteins, including SMO, to cilia (Liem et al. 2012), it appears IFT-A has a general role in recruiting membrane proteins, including the EVC proteins, to the cilium, and chondrocytes appear to be particularly sensitive to the loss of IFT-A.

The Tectonic complex localizes to the transition zones and appears to have complex tissue-specific functions in ciliogenesis (Table 1) (see Vaisse et al. 2016). Mutant fibroblasts assemble cilia but cells in the mutant embryonic node and mesenchymal cells adjacent to the neural tube fail to form cilia. As mutants show both defects in neural patterning and polydactyly, the tissue specificity of the Tectonic complex merits further study.

\section{LINEAGE DETERMINES WHICH CELLS HAVE PRIMARY CILIA IN THE MOUSE EMBRYO}

In cell culture, primary cilia are present in the $\mathrm{G}_{0}$ phase of the cell cycle and can be induced by serum removal (Plotnikova et al. 2009). In contrast, many proliferating cells in the mouse embryo and adult organs in vivo have a primary cilium. Scattered reports indicate that some specific cell types in the whole animal, such as acinar cells of the adult pancreas (Aughsteen 2001), lack primary cilia. Transgenic mice that carry fluorescent markers for basal bodies and cilia have been used to systematically identify ciliated and unciliated cells (Bangs et al. 2015). No cilia are present on cells of the preimplantation embryo; cilia first appear on cells of the epiblast lineage (the embryo proper) shortly after cavitation (E6.0) and all cells derived from the epiblast (ectoderm, mesoderm, and definitive endoderm) are ciliated in the midgestation embryo. In contrast, cells of extraembryonic lineages, the visceral endoderm and trophectoderm, have centrioles but lack primary cilia. Cells of both the trophectoderm lineage and from the embryonic mesoderm contribute to the placenta and cells of the visceral endoderm and mesoderm contribute to the yolk sac. These lineages lack cilia until at least E14.5 (Bangs et al. 2015).

Stem cell lines that correspond to the different embryonic lineages (Ralston and Rossant 2005) recapitulate the cilia status of the lineages in the embryo-all nondividing epiblast stem cells (EpiSCs) (which recapitulate the status of the E6.5 epiblast) are ciliated, whereas extraembryonic endoderm stem cells (XEN cells) and trophectoderm stem cells (TS cells) lack cilia (Bangs et al. 2015). For all three stem cell types, the presence or absence of primary cilia on embryo-derived stem cells is independent of the presence of serum.

The absence of primary cilia on cells of extraembryonic origin implies that these cells cannot respond to Hh ligands. The first time that Hh signaling is active in the mouse embryo is at the beginning of gastrulation, when Ihh expressed in the extraembryonic visceral endoderm signals to the adjacent epiblast derived extraembryonic mesoderm, which is ciliated. This is necessary to promote blood island formation (Fig. 4) (Farrington et al. 1997; Dyer et al. 2001). In the placenta, the only cells that respond to Hh signaling are embryo-derived ciliated cells that surround the fetal blood vessels (Fig. 4) (Jiang and Herman 2006). It is interesting to speculate that normal development of the placenta and yolk sac depends on preventing extraembryonic lineages from responding to Hh signals and this is achieved by blocking ciliogenesis in these cells. 

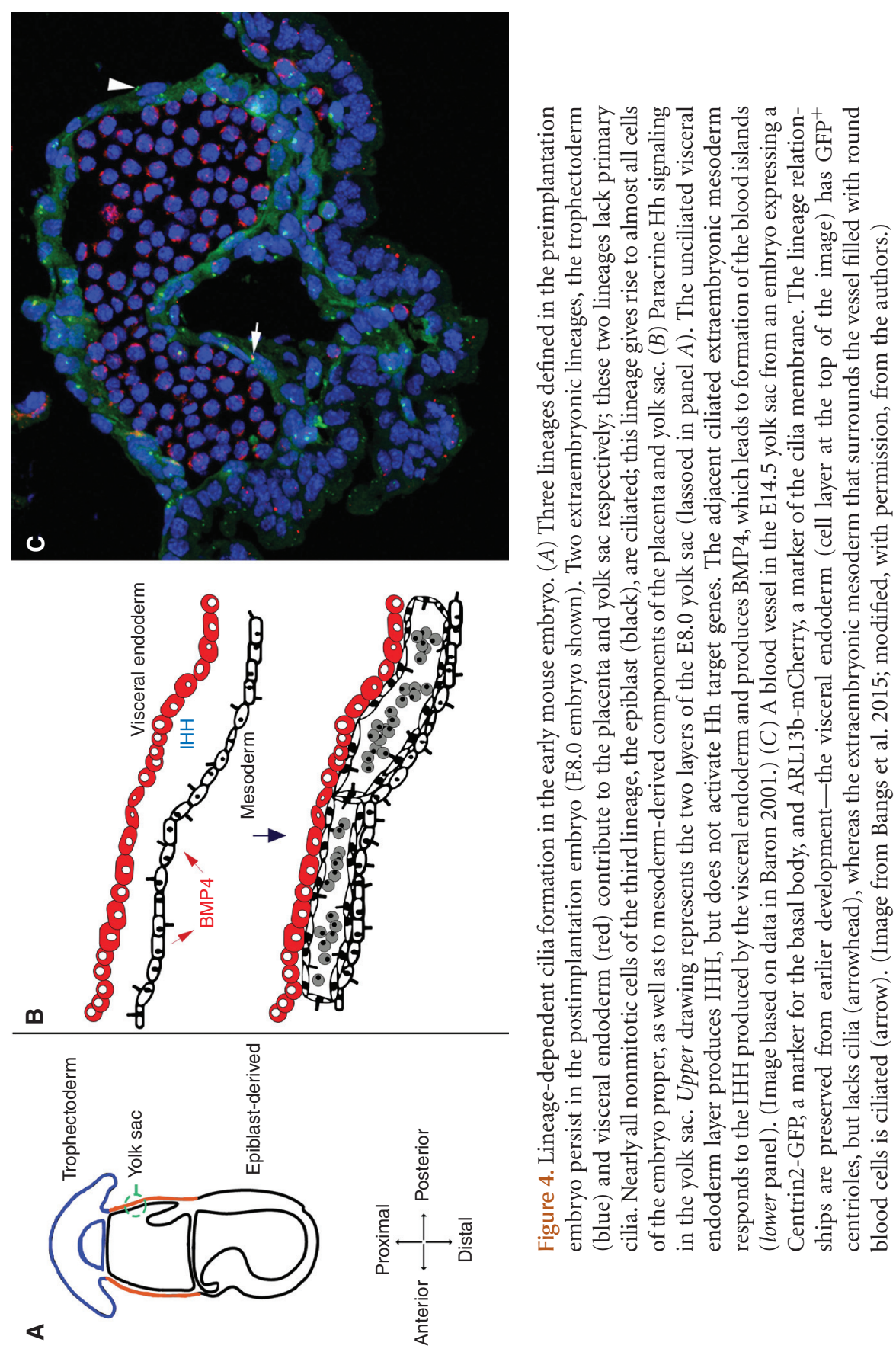

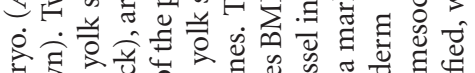

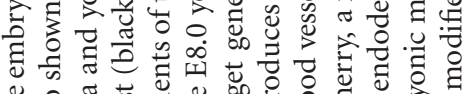

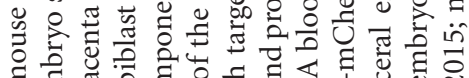

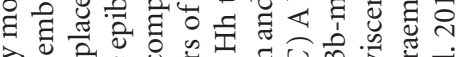
तें

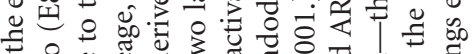
:

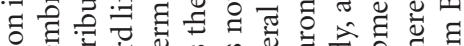

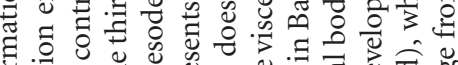

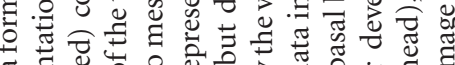

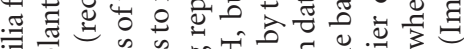

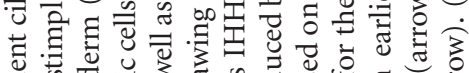

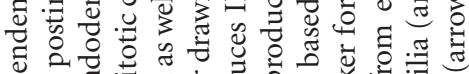

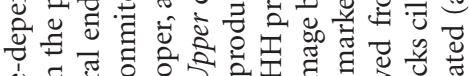
i. ש. +

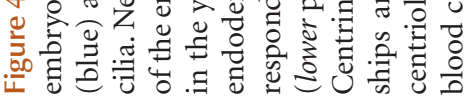


These cases of Hh ligand made by extraembryonic epithelia signaling to adjacent Hh-responsive ciliated cells reflect one of the common modes of Hh signaling in other organs. Paracrine signaling from ligand-producing cells to adjacent $\mathrm{Hh}$ responsive cells has been seen in a number of organs, including the digestive tract and the prostate ( $\mathrm{Yu}$ et al. 2009; Mao et al. 2010). Thus, it will be interesting to see whether tissue-specific absence of primary cilia enforces paracrine, rather than autocrine $\mathrm{Hh}$ signaling.

\section{CONCLUDING REMARKS}

Vertebrate Hedgehog signal transduction, which is essential for the development and maintenance of most organs, takes place in the primary cilium. The responses to $\mathrm{Hh}$ ligands are exquisitely sensitive to alterations in cilia structure-disruptions of many cilia components reduce the response to Hh ligands, but disruption of specific cilia proteins can also cause inappropriate activity of the pathway, and some proteins can be altered in different ways that enhance or interfere with Hh signal transduction. Dozens, and probably hundreds, of proteins are required to build the primary cilium; because of the many essential roles of $\mathrm{Hh}$ signaling, mutations in cilia genes collectively have a broad impact on human health.

The central effectors of Hh signaling, GLI proteins and the negative regulator SUFU, are regulated in the tiny compartment at the tip of the primary cilium. A single core conserved component of the Hh pathway, the kinesinfamily protein KIF7, has an essential role in organizing the cilia tip. The dual roles of KIF7 in Hh signal transduction and primary cilia structure argue for an ancient intertwining of Hh signal transduction with the structure of the primary cilium.

The distribution of primary cilia determines the ability of tissues to respond to Hh ligands, but the tissue distribution of primary cilia and the mechanisms that regulate cilia assembly and disassembly in vivo are poorly understood. A deeper understanding of the mechanisms that control cilia formation in vivo is likely to pro- vide the foundation for therapeutic interventions in both ciliopathies and cancer.

\section{ACKNOWLEDGMENTS}

We thank Meg Distinti for valuable assistance with the manuscript. Work in the Anderson laboratory in this area is supported by the $\mathrm{Na}$ tional Institutes of Health (NIH) Grants R37 HD03455 and R01 NS044385 to K.V.A. and the MSKCC Cancer Center Support Grant (P30 CA008748).

\section{REFERENCES}

${ }^{*}$ Reference is also in this collection

Aanstad P, Santos N, Corbit KC, Scherz PJ, Trinh le A, Salvenmoser W, Huisken J, Reiter JF, Stainier DY. 2009. The extracellular domain of Smoothened regulates ciliary localization and is required for high-level Hh signaling. Curr Biol 19: 1034-1039.

Ahn S, Joyner AL. 2004. Dynamic changes in the response of cells to positive Hedgehog signaling during mouse limb patterning. Cell 118: 505-516.

Alby C, Piquand K, Huber C, Megarbané A, Ichkou A, Legendre M, Pelluard F, Encha-Ravazi F, Abi-Tayeh G, Bessières B, et al. 2015. Mutations in KIAA0586 cause lethal ciliopathies ranging from a hydrolethalus phenotype to short-rib polydactyly syndrome. Am J Hum Genet 97: 311-318.

Amador-Arjona A, Elliott J, Miller A, Ginbey A, Pazour GJ, Enikolopov G, Roberts AJ, Terskikh AV. 2011. Primary cilia regulate proliferation of amplifying progenitors in adult hippocampus: Implications for learning and memory. J Neurosci 31: 9933-9944.

Aughsteen AA. 2001. The ultrastructure of primary cilia in the endocrine and excretory duct cells of the pancreas of mice and rats. Eur J Morphol 39: 277-283.

Bai CB, Stephen D, Joyner AL. 2004. All mouse ventral spinal cord patterning by hedgehog is Gli dependent and involves an activator function of Gli3. Dev Cell 6: 103-115.

Balaskas N, Ribeiro A, Panovska J, Dessaud E, Sasai N, Page KM, Briscoe J, Ribes V. 2012. Gene regulatory logic for reading the Sonic Hedgehog signaling gradient in the vertebrate neural tube. Cell 148: 273-284.

Bangs F, Antonio N, Thongnuek P, Welten M, Davey MG, Briscoe J, Tickle C. 2011. Generation of mice with functional inactivation of talpid3, a gene first identified in chicken. Development 138: 3261-72.

Bangs FK, Schrode N, Hadjantonakis AK, Anderson KV. 2015. Lineage specificity of primary cilia in the mouse embryo. Nat Cell Biol 17: 113-122.

Baron MH. 2001. Molecular regulation of embryonic hematopoiesis and vascular development: A novel pathway. J Hematother Stem Cell Res 10: 587-594.

Barzi M, Berenguer J, Menendez A, Alvarez-Rodriguez R, Pons S. 2010. Sonic-Hedgehog-mediated proliferation 
requires the localization of PKA to the cilium base. J Cell Sci 123: 62-69.

Bazzi H, Anderson KV. 2014. Acentriolar mitosis activates a p53-dependent apoptosis pathway in the mouse embryo. Proc Natl Acad Sci 111: E1491-E500.

Behal RH, Cole DG. 2013. Analysis of interactions between intraflagellar transport proteins. Methods Enzymol 524: 171-94.

Ben J, Elworthy S, Ng AS, van Eeden F, Ingham PW. 2011. Targeted mutation of the talpid 3 gene in zebrafish reveals its conserved requirement for ciliogenesis and Hedgehog signalling across the vertebrates. Development 138: 4969_4978.

Berbari NF, Kin NW, Sharma N, Michaud EJ, Kesterson RA, Yoder BK. 2011. Mutations in Traf3ip1 reveal defects in ciliogenesis, embryonic development, and altered cell size regulation. Dev Biol 360: 66-76.

Bielas SL, Silhavy JL, Brancati F, Kisseleva MV, Al-Gazali L, Sztriha L, Bayoumi RA, Zaki MS, Abdel-Aleem A, Rosti RO, et al. 2009. Mutations in INPP5E, encoding inositol polyphosphate-5-phosphatase E, link phosphatidyl inositol signaling to the ciliopathies. Nat Genet 41: 1032 1036.

Bishop GA, Berbari NF, Lewis J, Mykytyn K. 2007. Type III adenylyl cyclase localizes to primary cilia throughout the adult mouse brain. J Comp Neurol 505: 562-571.

Bizet AA, Becker-Heck A, Ryan R, Weber K, Filhol E, Krug P, Halbritter J, Delous M, Lasbennes MC, Linghu B, et al. 2015. Mutations in TRAF3IP1/IFT54 reveal a new role for IFT proteins in microtubule stabilization. Nat Commun 6: 8666 .

Bond J, Roberts E, Springell K, Lizarraga SB, Scott S, Higgins J, Hampshire DJ, Morrison EE, Leal GF, Silva EO, et al. 2005. A centrosomal mechanism involving CDK5RAP2 and CENPJ controls brain size. Nat Genet 37: 353-355.

Bonnafe E, Touka M, AitLounis A, Baas D, Barras E, Ucla C, Moreau A, Flamant F, Dubruille R, Couble P, et al. 2004. The transcription factor RFX3 directs nodal cilium development and left-right asymmetry specification. $\mathrm{Mol}$ Cell Biol 24: 4417-4427.

Botilde Y, Yoshiba S, Shinohara K, Hasegawa T, Nishimura H, Shiratori H, Hamada H. 2013. Cluap1 localizes preferentially to the base and tip of cilia and is required for ciliogenesis in the mouse embryo. Dev Biol 381: 203212.

Brailov I, Bancila M, Brisorgueil MJ, Miquel MC, Hamon M, Vergé D. 2000. Localization of 5- $\mathrm{HT}_{6}$ receptors at the plasma membrane of neuronal cilia in the rat brain. Brain Res 872: 271-275.

Bredrup C, Saunier S, Oud MM, Fiskerstrand T, Hoischen A, Brackman D, Leh SM, Midtbø M, Filhol E, Bole-Feysot C, et al. 2011. Ciliopathies with skeletal anomalies and renal insufficiency due to mutations in the IFT-A gene WDR19. Am J Hum Genet 89: 634-643.

Briscoe J, Ericson J. 2001 Specification of neuronal fates in the ventral neural tube. Curr Opin Neurobiol 11: 43-49.

Burke R, Basler K. 1997. Hedgehog signaling in Drosophila eye and limb development-Conserved machinery, divergent roles? Curr Opin Neurobiol 7: 55-61.

Cantagrel V, Silhavy JL, Bielas SL, Swistun D, Marsh SE, Bertrand JY, Audollent S, Attié-Bitach T, Holden KR,
Dobyns WB, et al. 2008. Mutations in the cilia gene $A R L 13 B$ lead to the classical form of Joubert syndrome. Am J Hum Genet 83: 170-179.

Caparrós-Martín JA, Valencia M, Reytor E, Pacheco M, Fernandez M, Perez-Aytes A, Gean E, Lapunzina P, Peters H, Goodship JA, et al. 2013. The ciliary Evc/Evc2 complex interacts with Smo and controls Hedgehog pathway activity in chondrocytes by regulating Sufu/Gli3 dissociation and Gli3 trafficking in primary cilia. Hum Mol Genet 22: 124-139.

Caparrós-Martín JA, De Luca A, Cartault F, Aglan M, Temtamy S, Otaify GA, Mehrez M, Valencia M, Vázquez L, Alessandri JL, et al. 2015. Specific variants in WDR35 cause a distinctive form of Ellis-van Creveld syndrome by disrupting the recruitment of the $\mathrm{EvC}$ complex and SMO into the cilium. Hum Mol Genet 24: 4126-4137.

Caspary T, Larkins CE, Anderson KV. 2007. The graded response to Sonic Hedgehog depends on cilia architecture. Dev Cell 12: 767-778.

Chávez M, Ena S, Van Sande J, de Kerchove d'Exaerde A, Schurmans S, Schiffmann SN. 2015. Modulation of ciliary phosphoinositide content regulates trafficking and Sonic Hedgehog signaling output. Dev Cell 34: 338-350.

Cheung HO, Zhang X, Ribeiro A, Mo R, Makino S, Puviindran V, Law KK, Briscoe J, Hui CC. 2009. The kinesin protein Kif7 is a critical regulator of Gli transcription factors in mammalian hedgehog signaling. Sci Signal 2: ra29.

Chizhikov VV, Davenport J, Zhang Q, Shih EK, Cabello OA, Fuchs JL, Yoder BK, Millen KJ. 2007. Cilia proteins control cerebellar morphogenesis by promoting expansion of the granule progenitor pool. J Neurosci 27: 9780-9789.

Cole DG. 1999. Kinesin-II, coming and going. J Cell Biol 147: 463-466.

Coles GL, Ackerman KG. 2013. Kif7 is required for the patterning and differentiation of the diaphragm in a model of syndromic congenital diaphragmatic hernia. Proc Nat Acad Sci 110: E1898-E905.

Corbit KC, Aanstad P, Singla V, Norman AR, Stainier DY, Reiter JF. 2005. Vertebrate smoothened functions at the primary cilium. Nature 437: 1018-1021.

Cortés CR, McInerney-Leo AM, Vogel I, Rondón Galeano MC, Leo PJ, Harris JE, Anderson LK, Keith PA, Brown MA, Ramsing M, et al. 2016. Mutations in human C2CD3 cause skeletal dysplasia and provide new insights into phenotypic and cellular consequences of altered C2CD3 function. Sci Rep 6: 24083.

Dagoneau N, Goulet M, Geneviève D, Sznajer Y, Martinovic J, Smithson S, Huber C, Baujat G, Flori E, Tecco L, et al. 2009. DYNC2H1 mutations cause asphyxiating thoracic dystrophy and short rib-polydactyly syndrome, type III. Am J Hum Genet 84: 706-711.

Damerla RR, Cui C, Gabriel GC, Liu X, Craige B, Gibbs BC, Francis R, Li Y, Chatterjee B, San Agustin JT, et al. 2015. Novel Jbts17 mutant mouse model of Joubert syndrome with cilia transition zone defects and cerebellar and other ciliopathy related anomalies. Hum Mol Genet 24: 39944005.

Davis EE, Zhang Q, Liu Q, Diplas BH, Davey LM, Hartley J, Stoetzel C, Szymanska K, Ramaswami G, Logan CV, et al 2011. TTC21B contributes both causal and modifying 
alleles across the ciliopathy spectrum. Nat Genet 43: 189196.

Dessaud E, Yang LL, Hill K, Cox B, Ulloa F, Ribeiro A, Mynett A, Novitch BG, Briscoe J. 2007. Interpretation of the Ssonic Hedgehog morphogen gradient by a temporal adaptation mechanism. Nature 450: 717-720.

Dessaud E, McMahon AP, Briscoe J. 2008. Pattern formation in the vertebrate neural tube: A sonic hedgehog morphogen-regulated transcriptional network. Development 135: 2489-503.

Dwyer ND, Adler CE, Crump JG, L'Etoile ND, Bargmann CI. 2001. Polarized dendritic transport and the AP-1 $\mu 1$ clathrin adaptor UNC-101 localize odorant receptors to olfactory cilia. Neuron 31: 277-287.

Dyer MA, Farrington SM, Mohn D, Munday JR, Baron MH. 2001. Indian hedgehog activates hematopoiesis and vasculogenesis and can respecify prospective neurectodermal cell fate in the mouse embryo. Development 128: 1717-1730.

Eggenschwiler JT, Espinoza E, Anderson KV. 2001. Rab23 is an essential negative regulator of the mouse Sonic hedgehog signalling pathway. Nature 412: 194-198.

Eguether T, San Agustin JT, Keady BT, Jonassen JA, Liang Y, Francis R, Tobita K, Johnson CA, Abdelhamed ZA, Lo CW, et al. 2014. IFT27 links the BBSome to IFT for maintenance of the ciliary signaling compartment. Dev Cell 31: 279-290.

Endoh-Yamagami S, Evangelista M, Wilson D, Wen X, Theunissen JW, Phamluong K, Davis M, Scales SJ, Solloway MJ, de Sauvage FJ, et al. 2009. The mammalian Cos2 homolog Kif7 plays an essential role in modulating $\mathrm{Hh}$ signal transduction during development. Curr Biol 19: $1320-1326$.

Farrington SM, Belaoussoff M, Baron MH. 1997. Wingedhelix, Hedgehog and Bmp genes are differentially expressed in distinct cell layers of the murine yolk sac. Mech Dev 62: 197-211.

Fehrenbach H, Decker C, Eisenberger T, Frank V, Hampel T, Walden U, Amann KU, Krüger-Stollfuß I, Bolz HJ, Häffner K, et al. 2014. Mutations in WDR19 encoding the intraflagellar transport component IFT144 cause a broad spectrum of ciliopathies. Pediatr Nephrol 29: 1451-1456.

Ferrante MI, Giorgio G, Feather SA, Bulfone A, Wright V, Ghiani M, Selicorni A, Gammaro L, Scolari F, Woolf AS, et al. 2001. Identification of the gene for oral-facialdigital type I syndrome. Am J Hum Genet 68: 569-576.

Ferrante MI, Zullo A, Barra A, Bimonte S, Messaddeq N, Studer M, Dollé P, Franco B. 2006. Oral-facial-digital type I protein is required for primary cilia formation and left-right axis specification. Nat Genet 38: 112-117.

Forbes AJ, Nakano Y, Taylor AM, Ingham PW. 1993. Genetic analysis of hedgehog signalling in the Drosophila embryo. Dev Suppl 1993: 115-124.

Garcia-Gonzalo FR, Corbit KC, Sirerol-Piquer MS, Ramaswami G, Otto EA, Noriega TR, Seol AD, Robinson JF Bennett CL, Josifova DJ, et al. 2011. A transition zone complex regulates mammalian ciliogenesis and ciliary membrane composition. Nat Genet 43: 776-784.

Garcia-Gonzalo FR, Phua SC, Roberson EC, Garcia G III, Abedin M, Schurmans S, Inoue T, Reiter JF. 2015. Phosphoinositides regulate ciliary protein trafficking to modulate Hedgehog signaling. Dev Cell 34: 400-409.
Goetz SC, Liem KF Jr, Anderson KV. 2012. The spinocerebellar ataxia-associated gene Tau tubulin kinase 2 controls the initiation of ciliogenesis. Cell 151: 847-858.

Halbritter J, Bizet AA, Schmidts M, Porath JD, Braun DA, Gee HY, McInerney-Leo AM, Krug P, Filhol E, Davis EE, et al. 2013. Defects in the IFT-B component IFT172 cause Jeune and Mainzer-Saldino syndromes in humans. Am J Hum Genet 93: 915-925.

Han YG, Spassky N, Romaguera-Ros M, Garcia-Verdugo JM, Aguilar A, Schneider-Maunoury S, Alvarez-Buylla A. 2008. Hedgehog signaling and primary cilia are required for the formation of adult neural stem cells. Nat Neurosci 11: 277-284.

Han YG, Kim HJ, Dlugosz AA, Ellison DW, Gilbertson RJ, Alvarez-Buylla A. 2009. Dual and opposing roles of primary cilia in medulloblastoma development. Nat Med 15: $1062-1065$.

Händel M, Schulz S, Stanarius A, Schreff M, ErdtmannVourliotis M, Schmidt H, Wolf G, Höllt V. 1999. Selective targeting of somatostatin receptor 3 to neuronal cilia. Neuroscience 89: 909-926.

Harfe B, Scherz PJ, Nissim S, Tian H, McMahon AP, Tabin CJ. 2004. Evidence for an expansion-based temporal Shh gradient in specifying vertebrate digit identities. Cell 118: 517-528.

Haycraft CJ, Banizs B, Aydin-Son Y, Zhang Q, Michaud EJ, Yoder BK. 2005. Gli2 and Gli3 localize to cilia and require the intraflagellar transport protein polaris for processing and function. PLoS Genet 1: e53.

Haycraft CJ, Zhang Q, Song B, Jackson WS, Detloff PJ, Serra R, Yoder BK. 2007. Intraflagellar transport is essential for endochondral bone formation. Development 134: $307-$ 316.

He M, Subramanian R, Bangs F, Omelchenko T, Liem KF Jr, Kapoor TM, Anderson KV. 2014. The kinesin-4 protein Kif7 regulates mammalian Hedgehog signalling by organizing the cilium tip compartment. Nat Cell Biol 16: $663-672$.

Heydeck W, Zeng H, Liu A. 2009. Planar cell polarity effector gene Fuzzy regulates cilia formation and Hedgehog signal transduction in mouse. Dev Dyn 238: 3035-3042.

Hoover AN, Wynkoop A, Zeng H, Jia J, Niswander LA, Liu A. 2008. C2cd3 is required for cilia formation and Hedgehog signaling in mouse. Development 135: 4049-4058.

Hou Y, Witman GB. 2015. Dynein and intraflagellar transport. Exp Cell Res 334: 26-34.

Houde C, Dickinson RJ, Houtzager VM, Cullum R, Montpetit R, Metzler M, Simpson EM, Roy S, Hayden MR, Hoodless PA, et al. 2006. Hippi is essential for node cilia assembly and Sonic hedgehog signaling. Dev Biol 300: 523-533.

Houlden H, Johnson J, Gardner-Thorpe C, Lashley T, Hernandez D, Worth P, Singleton AB, Hilton DA, Holton J, Revesz T, et al. 2007. Mutations in TTBK2, encoding a kinase implicated in tau phosphorylation, segregate with spinocerebellar ataxia type 11. Nat Genet 39: 1434-1436.

Huang P, Schier AF. 2009. Dampened Hedgehog signaling but normal Wnt signaling in zebrafish without cilia. $D e-$ velopment 136: 3089-3098. 
Huangfu D, Anderson KV. 2005. Cilia and Hedgehog responsiveness in the mouse. Proc Natl Acad Sci 102: 11325-11330.

Huangfu D, Liu A, Rakeman AS, Murcia NS, Niswander L, Anderson KV. 2003. Hedgehog signalling in the mouse requires intraflagellar transport proteins. Nature 426: 83-87.

Huber C, Wu S, Kim AS, Sigaudy S, Sarukhanov A, Serre V, Baujat G, Le Quan Sang KH, Rimoin DL, Cohn DH, et al. 2013. WDR34 mutations that cause short-rib polydactyly syndrome type III/severe asphyxiating thoracic dysplasia reveal a role for the NF-кB pathway in cilia. Am J Hum Genet 93: 926-931.

Huet D, Blisnick T, Perrot S, Bastin P. 2014. The GTPase IFT27 is involved in both anterograde and retrograde intraflagellar transport. eLife 3: e02419.

Humke EW, Dorn KV, Milenkovic L, Scott MP, Rohatgi R. 2010. The output of Hedgehog signaling is controlled by the dynamic association between Suppressor of Fused and the Gli proteins. Genes Dev 24: 670-682.

Ingham PW. 1998. Transducing Hedgehog: The story so far EMBO J 17: 3505-3511.

Ingham PW, McMahon AP. 2001. Hedgehog signaling in animal development: Paradigms and principles. Genes Dev 15: 3059-3087.

Jacoby M, Cox JJ, Gayral S, Hampshire DJ, Ayub M, Blockmans M, Pernot E, Kisseleva MV, Compère P, Schiffmann $\mathrm{SN}$, et al. 2009. INPP5E mutations cause primary cilium signaling defects, ciliary instability and ciliopathies in human and mouse. Nat Genet 41: 1027-1031.

Jenkins D, Seelow D, Jehee FS, Perlyn CA, Alonso LG, Bueno DF, Donnai D, Josifova D, Mathijssen IM, Morton JE, et al. 2007. RAB23 mutations in Carpenter syndrome imply an unexpected role for hedgehog signaling in cranialsuture development and obesity. Am J Hum Genet 80: $1162-1170$.

Jiang F, Herman GE. 2006. Analysis of Nsdhl-deficient embryos reveals a role for Hedgehog signaling in early placental development. Hum Mol Genet 15: 3293-3305.

Keady BT, Samtani R, Tobita K, Tsuchya M, San Agustin JT, Follit JA, Jonassen JA, Subramanian R, Lo CW, Pazour GJ. 2012. IFT25 links the signal-dependent movement of Hedgehog components to intraflagellar transport. Dev Cell 22: 940-951.

Kessler K, Wunderlich I, Uebe S, Falk NS, Gießl A, Brandstätter JH, Popp B, Klinger P, Ekici AB, Sticht H, et al. 2015. DYNC2LI1 mutations broaden the clinical spectrum of dynein-2 defects. Sci Rep 5: 11649.

Kim J, Hsia EY, Brigui A, Plessis A, Beachy PA, Zheng X. 2015. The role of ciliary trafficking in Hedgehog receptor signaling. Sci Signal 8: ra55.

Koyama E, Young B, Nagayama M, Shibukawa Y, EnomotoIwamoto M, Iwamoto M, Maeda Y, Lanske B, Song B, Serra R, et al. 2007. Conditional Kif3a ablation causes abnormal hedgehog signaling topography, growth plate dysfunction, and excessive bone and cartilage formation during mouse skeletogenesis. Development 134: 2159 2169.

Kyttälä M, Tallila J, Salonen R, Kopra O, Kohlschmidt N, Paavola-Sakki P, Peltonen L, Kestilä M. 2006. MKS1, encoding a component of the flagellar apparatus basal body proteome, is mutated in Meckel syndrome. Nat Genet 38: $155-157$.

Liem KF Jr, He M, Ocbina PJ, Anderson KV. 2009. Mouse Kif7/Costal2 is a cilia-associated protein that regulates Sonic hedgehog signaling. Proc Natl Acad Sci 106: 13377-13382.

Liem KF Jr, Ashe A, He M, Satir P, Moran J, Beier D, Wicking C, Anderson KV. 2012. The IFT-A complex regulates Shh signaling through cilia structure and membrane protein trafficking. J Cell Biol 197: 789-800.

Liu A, Wang B, Niswander LA. 2005. Mouse intraflagellar transport proteins regulate both the activator and repressor functions of Gli transcription factors. Development 132: 3103-3111.

Liu B, Chen S, Johnson C, Helms JA. 2014. A ciliopathy with hydrocephalus, isolated craniosynostosis, hypertelorism, and clefting caused by deletion of Kif3a. Reprod Toxicol 48: 88-97.

Long F, Zhang XM, Karp S, Yang Y, McMahon AP. 2001. Genetic manipulation of hedgehog signaling in the endochondral skeleton reveals a direct role in the regulation of chondrocyte proliferation. Development 128: 50995108.

Mak KK, Kronenberg HM, Chuang PT, Mackem S, Yang Y 2008. Indian hedgehog signals independently of PTHrP to promote chondrocyte hypertrophy. Development 135: 1947-1956.

Mao J, Kim BM, Rajurkar M, Shivdasani RA, McMahon AP. 2010. Hedgehog signaling controls mesenchymal growth in the developing mammalian digestive tract. Development 137: 1721-1729.

May SR, Ashique AM, Karlen M, Wang B, Shen Y, Zarbalis K, Reiter J, Ericson J, Peterson AS. 2005. Loss of the retrograde motor for IFT disrupts localization of Smo to cilia and prevents the expression of both activator and repressor functions of Gli. Dev Biol 287: 378-389.

Merrill AE, Merriman B, Farrington-Rock C, Camacho N, Sebald ET, Funari VA, Schibler MJ, Firestein MH, Cohn ZA, Priore MA, et al. 2009. Ciliary abnormalities due to defects in the retrograde transport protein DYNC2 $\mathrm{H} 1$ in short-rib polydactyly syndrome. Am J Hum Genet 84: $542-549$.

Mick DU, Rodrigues RB, Leib RD, Adams CM, Chien AS, Gygi SP, Nachury MV. 2015. Proteomics of primary cilia by proximity labeling. Dev Cell 35: 497-512.

Milenkovic L, Weiss LE, Yoon J, Roth TL, Su YS, Sahl SJ, Scott MP, Moerner WE. 2015. Single-molecule imaging of Hedgehog pathway protein Smoothened in primary cilia reveals binding events regulated by Patched1. Proc Natl Acad Sci 112: 8320-8325.

Mill P, Lockhart PJ, Fitzpatrick E, Mountford HS, Hall EA, Reijns MA, Keighren M, Bahlo M, Bromhead CJ, Budd P, et al. 2011. Human and mouse mutations in WDR35 cause short-rib polydactyly syndromes due to abnormal ciliogenesis. Am J Hum Genet 88: 508-515.

Miller KA, Ah-Cann CJ, Welfare MF, Tan TY, Pope K, Caruana G, Freckmann ML, Savarirayan R, Bertram JF, Dobbie MS, et al. 2013. Cauli: A mouse strain with an Ift140 mutation that results in a skeletal ciliopathy modelling Jeune syndrome. PLoS Genet 9: e1003746. 
Mukhopadhyay S, Rohatgi R. 2014. G-protein-coupled receptors, Hedgehog signaling and primary cilia. Semin Cell Dev Biol 33: 63-72.

Mukhopadhyay S, Wen X, Chih B, Nelson CD, Lane WS, Scales SJ, Jackson PK. 2010. TULP3 bridges the IFT-A complex and membrane phosphoinositides to promote trafficking of G-protein-coupled receptors into primary cilia. Genes Dev 24: 2180-2193.

Mukhopadhyay S, Wen X, Ratti N, Loktev A, Rangell L, Scales SJ, Jackson PK. 2013. The ciliary G-protein-coupled receptor Gpr161 negatively regulates the Sonic hedgehog pathway via cAMP signaling. Cell 152: 210223.

Nachury MV. 2014. How do cilia organize signalling cascades? Philos Trans R Soc Lond B Biol Sci 369: 20130465.

Niewiadomski P, Kong JH, Ahrends R, Ma Y, Humke EW, Khan S, Teruel MN, Novitch BG, Rohatgi R. 2014. Gli protein activity is controlled by multisite phosphorylation in vertebrate Hedgehog signaling. Cell Rep 6: 168181.

Nishina PM, North MA, Ikeda A, Yan Y, Naggert JK. 1998. Molecular characterization of a novel tubby gene family member, TULP3, in mouse and humans. Genomics 54: 215-220.

Norman RX, Ko HW, Huang V, Eun CM, Abler LL, Zhang Z, Sun X, Eggenschwiler JT. 2009. Tubby-like protein 3 (TULP3) regulates patterning in the mouse embryo through inhibition of Hedgehog signaling. Hum Mol Genet 18: $1740-1754$.

Nüsslein-Volhard C, Wieschaus E. 1980. Mutations affecting segment number and polarity in Drosophila. Nature 287: 795-801.

Nygaard MB, Almstrup K, Lindbæk L, Christensen ST, Svingen T. 2015. Cell context-specific expression of primary cilia in the human testis and ciliary coordination of Hedgehog signalling in mouse Leydig cells. Sci Rep 5: 10364.

Patterson VL, Damrau C, Paudyal A, Reeve B, Grimes DT, Stewart ME, Williams DJ, Siggers P, Greenfield A, Murdoch JN. 2009. Mouse hitchhiker mutants have spina bifida, dorso-ventral patterning defects and polydactyly: Identification of Tulp3 as a novel negative regulator of the Sonic hedgehog pathway. Hum Mol Genet 18: 1719-1739.

Perrault I, Saunier S, Hanein S, Filhol E, Bizet AA, Collins F, Salih MA, Gerber S, Delphin N, Bigot K, et al. 2012. Mainzer-Saldino syndrome is a ciliopathy caused by IFT140 mutations. Am J Hum Genet 90: 864-870.

Pigino G, Geimer S, Lanzavecchia S, Paccagnini E, Cantele F, Diener DR, Rosenbaum JL, Lupetti P. 2009. Electron-tomographic analysis of intraflagellar transport particle trains in situ. J Cell Biol 187: 135-148.

Plotnikova OV, Pugacheva EN, Golemis EA. 2009. Primary cilia and the cell cycle. Methods Cell Biol 94: 137-160.

Qin J, Lin Y, Norman RX, Ko HW, Eggenschwiler JT. 2011. Intraflagellar transport protein 122 antagonizes Sonic Hedgehog signaling and controls ciliary localization of pathway components. Proc Natl Acad Sci 108: 14561461.

Ralston A, Rossant J. 2005. Genetic regulation of stem cell origins in the mouse embryo. Clin Genet 68: 106-112.
Regard JB, Malhotra D, Gvozdenovic-Jeremic J, Josey M, Chen M, Weinstein LS, Lu J, Shore EM, Kaplan FS, Yang Y. 2013. Activation of Hedgehog signaling by loss of GNAS causes heterotopic ossification. Nat Med 19: $1505-1512$.

Reiter JF, Skarnes WC. 2006. Tectonic, a novel regulator of the Hedgehog pathway required for both activation and inhibition. Genes Dev 20: 22-27.

Rix S, Calmont A, Scambler PJ, Beales PL. 2011. An Ift80 mouse model of short rib polydactyly syndromes shows defects in hedgehog signalling without loss or malformation of cilia. Hum Mol Genet 20: 1306-1314.

Rohatgi R, Milenkovic L, Scott MP. 2007. Patched1 regulates hedgehog signaling at the primary cilium. Science 317: 372-376.

Ruiz-Perez VL, Tompson SW, Blair HJ, Espinoza-Valdez C, Lapunzina P, Silva EO, Hamel B, Gibbs JL, Young ID, Wright MJ, et al. 2003. Mutations in two nonhomologous genes in a head-to-head configuration cause Ellis-van Creveld syndrome. Am J Hum Genet 72: 728-732.

Ruiz-Perez VL, Blair HJ, Rodriguez-Andres ME, Blanco MJ, Wilson A, Liu YN, Miles C, Peters H, Goodship JA. 2007. Evc is a positive mediator of Ihh-regulated bone growth that localises at the base of chondrocyte cilia. Development 134: 2903-2912.

Santos N, Reiter JF. 2014. A central region of Gli2 regulates its localization to the primary cilium and transcriptional activity. J Cell Sci 127: 1500-1510.

Spassky N, Han YG, Aguilar A, Strehl L, Besse L, Laclef C, Ros MR, Garcia-Verdugo JM, Alvarez-Buylla A. 2008. Primary cilia are required for cerebellar development and Shh-dependent expansion of progenitor pool. Dev Biol 317: 246-259.

Srour M, Schwartzentruber J, Hamdan FF, Ospina LH, Patry L, Labuda D, Massicotte C, Dobrzeniecka S, Capo-Chichi JM, Papillon-Cavanagh S, et al. 2012. Mutations in C5ORF42 cause Joubert syndrome in the French Canadian population. Am J Hum Genet 90: 693-700.

Stephen LA, Tawamie H, Davis GM, Tebbe L, Nürnberg P, Nürnberg G, Thiele H, Thoenes M, Boltshauser E, Uebe S, et al. 2015. TALPID3 controls centrosome and cell polarity and the human ortholog KIAA0586 is mutated in Joubert syndrome (JBTS23). eLife 4: e08077.

Swiderski RE, Nakano Y, Mullins RF, Seo S, Bánfi B. 2014. A mutation in the mouse $t t c 26$ gene leads to impaired hedgehog signaling. PLoS Genet 10: e1004689.

Tanos BE, Yang HJ, Soni R, Wang WJ, Macaluso FP, Asara JM, Tsou MF. 2013. Centriole distal appendages promote membrane docking, leading to cilia initiation. Genes Dev 27: $163-168$.

Tay SY, Yu X, Wong KN, Panse P, Ng CP, Roy S. 2010. The iguana/DZIP1 protein is a novel component of the ciliogenic pathway essential for axonemal biogenesis. Dev Dyn 239: 527-534.

Taylor SP, Dantas TJ, Duran I, Wu S, Lachman RS, University of Washington Center for Mendelian Genomics Consortium, Nelson SF, Cohn DH, Vallee RB, Krakow D. 2015. Mutations in DYNC2LI1 disrupt cilia function and cause short rib polydactyly syndrome. Nat Commun 6: 7092 .

Tong CK, Han YG, Shah JK, Obernier K, Guinto CD, Alvarez-Buylla A. 2014. Primary cilia are required in a unique 
subpopulation of neural progenitors. Proc Natl Acad Sci 111: $12438-12443$.

Toriyama M, Lee C, Taylor SP, Duran I, Cohn DH, Bruel AL, Tabler JM, Drew K, Kelly MR, Kim S, et al. 2016. The ciliopathy-associated CPLANE proteins direct basal body recruitment of intraflagellar transport machinery. Nat Genet 48: 648-656.

Tran PV, Haycraft CJ, Besschetnova TY, Turbe-Doan A, Stottmann RW, Herron BJ, Chesebro AL, Qiu H, Scherz PJ, Shah JV, et al. 2008. THM1 negatively modulates mouse sonic hedgehog signal transduction and affects retrograde intraflagellar transport in cilia. Nat Genet 40: 403-410.

Tuson M, He M, Anderson KV. 2011. Protein kinase A acts at the basal body of the primary cilium to prevent Gli2 activation and ventralization of the mouse neural tube. Development 2011 138: 4921-4930.

* Vaisse C, Reiter JF, Berbari NF. 2016. Cilia and obesity. Cold Spring Harb Perspect Biol doi: 10.1101/cshper spect.a028217.

Vuolo L, Herrera A, Torroba B, Menendez A, Pons S. 2015 Ciliary adenylyl cyclases control the Hedgehog pathway. $J$ Cell Sci 128: 2928-2937.

Walczak-Sztulpa J, Eggenschwiler J, Osborn D, Brown DA, Emma F, Klingenberg C, Hennekam RC, Torre G, Garshasbi M, Tzschach A, et al. 2010. Cranioectodermal dysplasia, Sensenbrenner syndrome, is a ciliopathy caused by mutations in the IFT122 gene. Am J Hum Genet 86: 949 956.

Wang C, Low WC, Liu A, Wang B. 2013. Centrosomal protein DZIP1 regulates Hedgehog signaling by promoting cytoplasmic retention of transcription factor GLI3 and affecting ciliogenesis. J Biol Chem 288: 29518-29529.
Wang H, Kane AW, Lee C, Ahn S. 2014. Gli3 repressor controls cell fates and cell adhesion for proper establishment of neurogenic niche. Cell Rep 8: 1093-1104.

Weatherbee SD, Niswander LA, Anderson KV. 2009. A mouse model for Meckel syndrome reveals Mks1 is required for ciliogenesis and Hedgehog signaling. Hum Mol Genet 18: 4565-4575.

Wen X, Lai CK, Evangelista M, Hongo JA, de Sauvage FJ, Scales SJ. 2010. Kinetics of hedgehog-dependent fulllength Gli3 accumulation in primary cilia and subsequent degradation. Mol Cell Biol 30: 1910-1922.

Wong SY, Seol AD, So PL, Ermilov AN, Bichakjian CK, Epstein EH Jr, Dlugosz AA, Reiter JF. 2009. Primary cilia can both mediate and suppress Hedgehog pathway-dependent tumorigenesis. Nat Med 15: 1055-1061.

Yadav SP, Sharma NK, Liu C, Dong L, Li T, Swaroop A. 2016. Centrosomal protein $\mathrm{CP} 110$ controls maturation of the mother centriole during cilia biogenesis. Development 143: 1491-1501.

Ye X, Zeng H, Ning G, Reiter JF, Liu A. 2014. C2cd3 is critical for centriolar distal appendage assembly and ciliary vesicle docking in mammals. Proc Natl Acad Sci 111: 21642169.

Yin Y, Bangs F, Paton IR, Prescott A, James J, Davey MG, Whitley P, Genikhovich G, Technau U, Burt DW, et al. 2009. The Talpid3 gene (KIAA0586) encodes a centrosomal protein that is essential for primary cilia formation. Development 136: 655-664.

Yu M, Gipp J, Yoon JW, Iannaccone P, Walterhouse D, Bushman W. 2009. Sonic Hedgehog-responsive genes in the fetal prostate. J Biol Chem 284: 5620-5629.

Zeng H, Hoover AN, Liu A. 2010. PCP effector gene Inturned is an important regulator of cilia formation and embryonic development in mammals. Dev Biol 339: 418-428. 


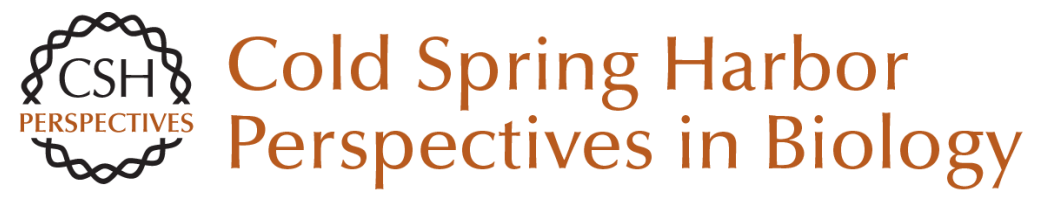

\section{Primary Cilia and Mammalian Hedgehog Signaling}

Fiona Bangs and Kathryn V. Anderson

Cold Spring Harb Perspect Biol 2017; doi: 10.1101/cshperspect.a028175 originally published online November 23, 2016

\section{Subject Collection Cilia}

Ciliary Mechanisms of Cyst Formation in Polycystic Kidney Disease

Ming Ma, Anna-Rachel Gallagher and Stefan Somlo

Photoreceptor Cilia and Retinal Ciliopathies Kinga M. Bujakowska, Qin Liu and Eric A. Pierce

G-Protein-Coupled Receptor Signaling in Cilia Kirk Mykytyn and Candice Askwith

Evolution of Cilia David R. Mitchell

Transition Zone Migration: A Mechanism for Cytoplasmic Ciliogenesis and Postaxonemal Centriole Elongation

Tomer Avidor-Reiss, Andrew Ha and Marcus L. Basiri

Cilia and Obesity

Christian Vaisse, Jeremy F. Reiter and Nicolas F. Berbari

Posttranslational Modifications of Tubulin and Cilia

Dorota Wloga, Ewa Joachimiak, Panagiota Louka, et al.
Cilia in Left-Right Symmetry Breaking Kyosuke Shinohara and Hiroshi Hamada

Discovery, Diagnosis, and Etiology of Craniofacial Ciliopathies Elizabeth N. Schock and Samantha A. Brugmann

Axoneme Structure from Motile Cilia Takashi Ishikawa

Cilia and Ciliopathies in Congenital Heart Disease Nikolai T. Klena, Brian C. Gibbs and Cecilia W. Lo

Sperm Sensory Signaling Dagmar Wachten, Jan F. Jikeli and U. Benjamin Kaupp

\section{Primary Cilia and Coordination of Receptor} Tyrosine Kinase (RTK) and Transforming Growth Factor $\beta$ (TGF- $\beta$ ) Signaling Søren T. Christensen, Stine K. Morthorst, Johanne B. Mogensen, et al.

Primary Cilia and Mammalian Hedgehog Signaling Fiona Bangs and Kathryn V. Anderson

For additional articles in this collection, see http://cshperspectives.cshlp.org/cgi/collection/

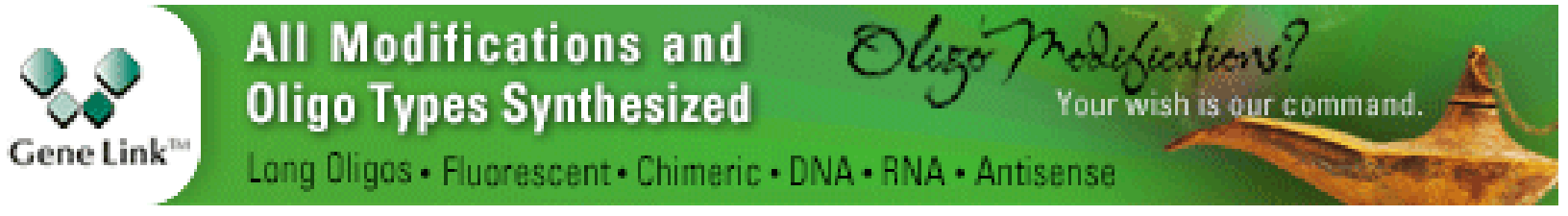


Radial Spokes--A Snapshot of the Motility Regulation, Assembly, and Evolution of Cilia and Flagella

Xiaoyan Zhu, Yi Liu and Pinfen Yang
Cilia and Mucociliary Clearance

Ximena M. Bustamante-Marin and Lawrence E. Ostrowski

For additional articles in this collection, see http://cshperspectives.cshlp.org/cgi/collection/

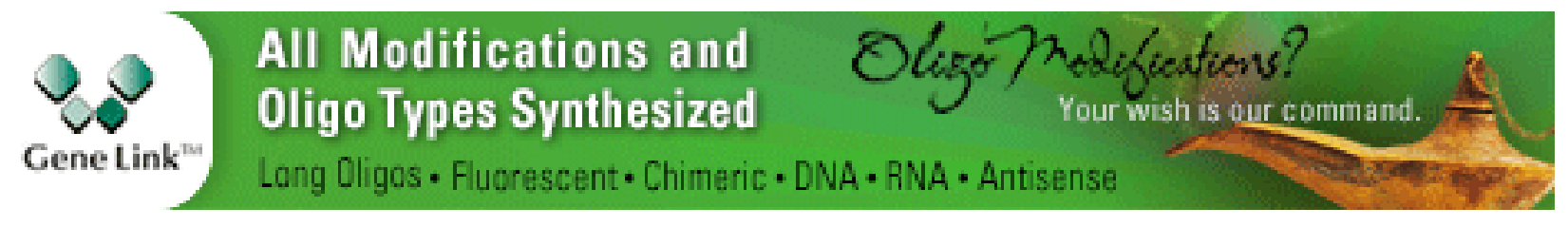

Copyright @ 2017 Cold Spring Harbor Laboratory Press; all rights reserved 